\title{
Roma İnancında Ev Kültleri ve Mezarlardaki Naiskoslu Nişler Üzerine Bir Öneri
}

\section{Household Cults in Roman Religion and A Proposal for Naiskos Niches in Graves}

\author{
Tuna Akçay ${ }^{1}$ (D)
}

1Sorumlu yazar/Corresponding author: Tuna Akçay (Öğr. Gör. Dr.), Ankara Hacı Bayram Veli Üniversitesi, Edebiyat Fakültesi, Arkeoloji Bölümü, Ankara, Türkiye E-mail:akcaytuna@gmail.com Orcid ID: 0000-0003-3090-8354

Başvuru/Submitted: 26.11 .2019 Kabul/Accepted: 28.11 .2019

Atıf/Citation: Akcay, T. (2019). Roma inancında ev kültleri ve mezarlardaki naiskoslu nişler üzerine bir öneri. Anadolu Araştırmaları-Anatolian Research, 22, 75-106.

https://doi.org/10.26650/anar.2019.22.651105
Öz

Roma dünyasında ritüellerinin uygulandığı mekan ya da alanlar da çeşitlilik göstermekte, tapınaklar, sunaklar, meydanlar, açık hava ritüel alanları, mezarlıkların yanısıra evlerde de ritüeller gerçekleştirilmektedir. Evlerdeki ritüellerin uygulanmasında iki farklı anlayış söz konusudur. Bunlardan ilki, evde devletin tanımladığı ve kabul ettiği kültlere bağlı olan ritüellerin gerçekleştirilmesidir. Diğeri ise paterfamilias'ın bir rahip görevi üstlenerek, ailenin kendine has kültleri kapsamındaki ritüellerin aile bireylerince yerine getirilmesinden oluşmaktadır. Her iki durumda da "ev", bu ritüellerin uygulanışı sırasında dışarıdan müdahale edilemeyen ve yönetilemeyen bir kült yeri, aynı zamanda korunan bir alandır. Evlerde gerçekleştirilen ritüellerde lares, genius ve dii penates kültleri ve ona dair ritüel pratikleri ön plana çıkmakta, bu kültlerin uygulama biçimlerindeki farklııklar ve benzerlikler çalışmamızda ele alınmaktadır. Konu, arkeolojik veriler ve antik kaynakların sağladıkları bilgiler bağlamında değerlendirilmekte; Roma evlerinde ritüellerin nerelerde gerçekleştiği konusuna da değinilmektedir. Özellikle larariumlar, başta Pompeii olmak üzere önemli Roma kentlerindeki örnekleriyle tanıtılmaktadır. Ayrıca, bir öneri olarak Olba'daki tapınak cepheli kaya mezarı örnek gösterilerek mezar odalarındaki naiskoslu nişlerin de aslında birer lararium'u temsil etmekte olabileceği önerilmektedir.

Anahtar Kelimeler: Ev Kültleri, Lares, Genius, Dii Penates, Lararium

\section{ABSTRACT}

Areas where religious rituals took place in the Roman world varied: Temples, altars, city squares, open air ritual areas and cemeteries as well as houses were all places that hosted rituals. House rituals are of two different types. The first are those that are carried out by family members, in accordance with the cult as defined and accepted by the state. In the second type, the family practices its own rituals with the paterfamilias assuming the role of the priest. In both types, "house" during the ritual is a cult area that is immune to outside interference and governance and is a protected space. Overall house rituals feature lares, genius and dii penates cults and practices related to those, the similarities and differences of which are studied in this article. The subject is evaluated based on archaeological evidence and the information provided by ancient sources, accompanied by discussions of the places inside houses where rituals took place. In particular, lararia across Roman cities are introduced with examples, with the primary city being Pompeii. In addition, taking the rock-cut tomb with a temple façade in Olba as an example, it is proposed that naiskos niches in the burial chambers likely each represent a lararium.

Keywords: Home Cults, Lares, Genius, Dii Penates, Lararium 


\section{EXTENDED ABSTRACT}

To understand the religion of Rome, it is necessary to understand the family structure, the basic unit of society. Also, the wide territory of the country and especially the relations with Eastern societies create a belief system with an eclectic structure. In the Roman world, house rituals structured and shaped everyday life. It is possible to evaluate house rituals in two ways. The first of these is the rituals including slaves and servants as well as family members. The second is family-specific cult practices applied only by the paterfamilias, his wife and children. In Rome, houses are not only places where the family lives, but also the areas where many social and religious practices take place. Beyond collecting the family, belongings or animals under one roof, the house is a holy place, which symbolizes and protects the family unity. In addition to these, the house is also a sacred place where ancestors are remembered. The first aim of these rituals is material-oriented and for the needs of the house. However, they are also carried out for dead ancestors or gods. Although there are no significant differences between these two aims, these rituals are for sure carried out by considering the peace and abundance of the house. In the Roman world, the public spaces where ritual practices performed in the presence of public are called sacra publica, and cult practices, performed only within the family are called sacra privata. In this way, sacra publica expresses the ritual acts of the state, which are open to the public. Society can freely participate in these ritual acts. Preservation, financing and sanctification of the cult is the responsibility of the local government. These rituals are not an option for society, but an obligation to be carried out. They are organized by the central or local government and regarded as compulsory ritual practices to be followed. This obligation should be considered as a political component of Roman religion within the state. Since religion and politics are in line with each other in Rome, these ritual practices became obligatory within certain rules. The Romans participate in these ritual practices obliged by the state and contribute to the peace with the gods (pax deourum). However, it is stated that this coercion caused dissatisfaction of some Roman citizens, and therefore some cults from the East were accepted. This situation has led to the development of various cults in the country. Sacra privata, apart from public compulsion, allows people to live their individual beliefs in more free and private spaces. "Privatus" means separate from the state, limited to a single individual or belonging to a single individual (Georges, 1902, s.633). This understanding enables individuals to worship the cults they believe in and this broad perspective makes it possible to perform ritual for family cults and ancestors (gentes) in the house (religio domestica). In this context, the places or areas where the rituals are practiced in the Roman world are also varied: in addition to temples, altars, city squares, open air ritual areas and cemeteries, rituals are also performed in the houses. There are two different approaches to the practice of the rituals in the houses. The first of these is the practice of rituals in the house, which depend on the cults defined and accepted by the state. In the second type, the family practices its own family-specific 
cult rituals with the paterfamilias assuming the role of the priest. In both cases, the "house" during the ritual is a cult place that can not be interfered and managed from outside and it is also a protected space. In the house rituals stand out lares, genius and dii penates cults and ritual practices related to those. The differences and similarities in the practice of these cults are handled in our study. The subject is evaluated based on archaeological evidence and the information provided by ancient sources. It is also mentioned where the rituals take place in Roman houses. In particular, larariums are introduced with examples from important Roman cities, initially Pompeii. In addition, taking the rock-cut tomb with a temple facade in Olba as an example, it is proposed that naiskos niches in the burial chambers likely each represent a lararium. The rock-cut tomb with a temple facade provides important results regarding the cult of the dead in Olba. In the Roman world, the tomb is considered and designed as the house of the dead for the other world. In Roman religion, tombs are regarded as "domus aeterna", in other words eternal house of the decedent. In the light of this basic information, some rituals in the tombs or graves are similar to the ritual practices in the houses. For the Roman world the naiskos niches in the burial chamber may have the characteristics of larariums in Roman dwellings, especially both formally and functionally. 


\section{Giriş}

Roma'da evler sadece ailenin yaşamını sürdürdüğü yerler değil, aynı zamanda birçok sosyal ve dini pratiğin gerçekleştirildiği alanlardır. Ev, aileyi, eşyalarını ya da hayvanlarını bir çatı altında toplamasının ötesinde aile birliğini simgeleyen, koruyan ve kollayan, ataların anıldığı kutsal bir mekan, baba ocağıdır. Bu durumu Cicero şöyle vurgular (Cicero, de domo sua, 41, 109.)

Her bir yurttaş için dünyadaki en mukaddes, en kutsanmış yer onun evidir. Onun kutsal ocağı orada, ev tanrıları, dinsel tapınımının, ev ritüellerinin merkezi işte orası ${ }^{1}$

Roma dünyasında, inanç sisteminde özel önemi ve değeri olan evin ve ona verilen kutsallığın yansıması olan ev ritüellerinin arkeolojik ve yazınsal veriler bağlamında değerlendirilmesinde yarar bulunmaktadır.

Roma dini, içinde pek çok inanç ve kültü barındırması bakımından eklektik bir yapıya sahiptir. Roma dini inancında tek bir yapıdan bahsedilemeyeceği için onu bir ritüeller bütünü olarak tanımlamak olasıdır. Roma inancında ritüellerin gerçekleştirildiği yerler çeşitlilik göstermektedir. Bu yerler, insanların ortak kullanım alanları ya da dernekler olabileceği gibi ailenin yaşadığı özel konutlar da olabilmektedir (Rüpke, 2001, s.19).

Roma dünyasında ev kültleri, gündelik hayatı yapılandırmakta ve biçimlendirmektedir. Evdeki kültik uygulamaları iki şekilde değerlendirmek mümkündür. Bunlardan ilki, aile bireylerinin yanısıra köleler ve hizmetlilerin de içinde bulunduğu ritüellerdir. Diğeri ise sadece paterfamilias, karısı ve çocukları için geçerli olan aileye özel kült pratikleridir (Deissmann 1998, s. 415). Bu ritüellerdeki ilk amaç, materyal odaklı ve evin ihtiyaçlarına yöneliktir. Ancak, bir yandan da ölmüş atalar ya da tanrılar için yapılmaktadırlar (Rives, 2007, s.117). Her iki amaç arasında keskin ayrım olmamakla birlikte, elbette ki evin huzuru ve bereketi düşünülerek bu ritüeller gerçekleştirilmektedir.

Roma dünyasında toplumun hazır bulunduğu ritüel uygulamalarının yapıldığı kamusal alanlara sacra publica, sadece aile içinde gerçekleştirilen kült uygulamalarına da sacra privata denmektedir (Wachsmuth, 1980, s.44). Böylece, sacra publica devlet eliyle kamuya açık resmi bir niteliği olan, toplumun serbest bir şekilde dahil olabileceği ritüel eylemlerini ifade etmektedir. Kültün korunması, finanse edilmesi, yerin kutsanması yerel yönetimin sorumluluğundadır. Bu kültler toplum için bir seçenek değil, uygulanması zorunlu bir vazifedir. Bunlar, merkezi ya da yerel yönetim tarafından organize edilmekte ve uyulması zorunlu ritüel uygulamalar olarak nitelenmektedirler (Rüpke, 2001, s.29). Bu zorunluluk Roma dininin devlet içinde politik bileşeni ile ilgili sayılmalıdır. Roma'da din ile politika

1 Makalede yer alan Latince metin çevirileri konusunda yardımları için Mersin Üniversitesi Arkeoloji Bölümü’nden Klasik Filolog Öğr. Gör. Murat Özyıldırım hocama gönülden teşekkür ederim. 
aynı eksende gittiği için bu ritüel uygulamalar da belirli kurallar içinde zorunlu hale gelmiştir. Romalılar, devletin zorunlu kıldığı bu ritüel uygulamalarına katılıp, tanrılarla olan barışa (pax deourum) katkıda bulunmaktadırlar. Ancak bu zorlamanın bazı Roma vatandaşlarında memnuniyetsizliğe neden olduğu ve bu nedenle Doğu'dan gelen bazı kültlerin kabul gördüğü; durumun ülkede çeşitli kültlerin gelişmesine yol açtı̆̆ belirtilmektedir (Orr, 1978, s.1559).

Sacra privata ise kamu baskısından ayrı, insanların bireysel inançlarını daha özgür ve özel alanlarda yaşamasını sağlamaktadır. "Privatus", devletten ayrı, tek bir birey ile sınırlı ya da tek bir bireye ait anlamına gelmektedir (Georges, 1902, s.633). Bu anlayış bireylerin kendi içinde inandığı kültlere tapınım gerçekleştirmesini sağlamakta; bu geniş bakış açısı, evlerde (religio domestica) aile kültlerine ve atalara (gentes) ritüel gerçekleştirmeyi mümkün k1lmaktadır (Rüpke, 2001, s.31).

Öte yandan, Roma dünyasında yukarıda sözü edilen farklı ritüel pratikler arasında keskin bir ayrım da söz konusu değildir. Bu nedenle farklı alanlardaki ritüelleri birbirinden ayrı bir perspektifle değerlendirmek doğru olmayacaktır. Örneğin, evi ve aile ocağını simgeleyen Hestia, hem evlerde tapınılmakta, hem de kamusal alanda, Forum Romanum'da Vesta Rahibeleri onun ateşini korumaktadırlar.

\section{Ev Kültleri}

Roma evindeki kültik uygulamalarda iki farklı ritüel anlayışı söz konusudur. Bunlardan ilki evde devletin tanımladığı ve kabul ettiği ritüellerin, kültlerin gerçekleştirilmesi; diğeri de paterfamilias'ın bir rahip görevi üstlenerek ailenin kendine has kültlerini ve ritüellerini aile bireylerine uygulatması niteliğindedir (Kaiser, 1965, s.51; Gradel, 2002, s.206).

Ritüelin uygulanacağı zaman evin sakinleri dini bir topluluğu oluşturmakta ve dini ritüeller bütün ailenin günlük yaşamını önemli bir şekilde etkilemektedir. Ev bu anlayış çerçevesinde ritüellerin yapılacağı zaman kutsal bir alana dönüştürülmektedir (Wachsmuth, 1980, s.44). Cicero bu durum ile ilgili önemli bilgiler verir (Cic. dom. 109).

Her din tarafindan, her vatandaşın özel evi (domus) olarak değerlendirilen şeyden $<$ yerden> daha dokunulmaz olan nedir? Burada Sunaklar, ocaklar, ev tanrları, kültler (sacra), dini adetler (dinler), ritüeller bulunmaktadır. Işste herkes için, kimsenin oradan zorla kaçırılamayacağı böyle dokunulmaz bir kutsal alan vardır (sanctum).

Evlerin özel, dokunulmaz atmosferi içinde uygulanan ve Cicero'nun ifadesine göre atalardan kalma olan, kamuya açık olmayan alanlarda gerçekleştirilen ritüeller için devletin sorumluluğu olup olmadığı sorusuna cevap, Roma inancının kökenlerinden biri olan Yunanlı kökenlerde aranabilir. Aristoteles'in Atina'da kamu görevine başvuran birinden bahsettiği bölüm ev ve kamu kültlerini açıklayan önemli bir metindir: 
Ilk denemelerde şu soruyu soruyorlar; ilk önce baban kim ve nereli? Babanın babası kim? Annen kim, annenin babası kim ve nereli? Apollon Patroos ve Zeus Herkeios'a inanıp inanmadiğg ve bu tapinakların nerede olduğu, aile mezarliğının nerede olduğu atalarına iyi

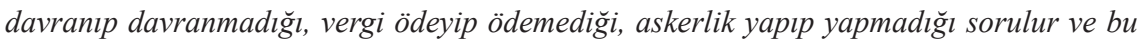
sorular cevaplandıktan sonra şahitler çağırılır (Arist. ath. pol. 55,3).

Bu metin, Yunan dünyasında devletin gözünde ailede geçerli olan inançlara verilen önemi yansitmaktadır. Metinde bahsedilen Apollon Patroos'un kült heykeli Atina agorasında, Zeus Eleutherios stoasının güneyinde yer almakta; Zeus Herkeios sunağ1 ise Atina'daki Pandroseion'da ve Zeus'un sınır muhafızları olarak ritüel gerçekleştirilen Dipylon'da yer almaktadır (Schwabl, 1972, s.309). Zeus Herkeios, Yunan inancinda yerel kimlikli en eski tanrılardan biridir (Sjövall, 1931, s.7). Herkeios sıfatı ile evlerin koruyucu tanrısı olarak bilinmektedir (Nilsson, 1992, s.402). Apollon Patroos hakkında ise çok fazla bilgi bulunmamakla birlikte Ionialıların atası olarak bilinmekte, hem devlet hem de ev kültlerinde önemli bir yere sahip bulunmaktadır (Palagia, 1980, s.13). Her iki kült de kamusal ya da kamusal olmayan alanlarda tanınmakta ve bu durum Atina'da ev kültleri ile kamu tarafından tanınan kültlerin yakın ilişkisini göstermektedir. Aristoteles'in yazdıkları, Yunanlılarda yönetimlerin hem hanelerdeki inançları bilmek ve kontrol etmek istediklerini, hem de devletin bağlayıcı bir dini temelinin olmasının amaçlandığını göstermektedir. Ayrıca, insanların da bu inançtan kopmamasının arzu edildiği anlaşılmaktadır.

Yukarıda örnek olarak verilen Yunan modelinde olduğu gibi Roma dünyasında da devletin dinsel inançlar ve kültlerle ilgili kontrol sistemini yasalar çerçevesinde sağladiğ görülmektedir. Cicero, aşağıdaki ifadesinde ev içinde geçerli inançların aile babasının ölümünden sonra da rahiplerin sorumluluğu altında ve mirasçıların yükümlülüklerini yerine getirmesi ile devamından söz etmektedir:

Bu haklar rahiplerin vekaleti sayesinde korunmakta, böylece aile kurbanları evin babasının ölümünden sonra bitmez ve onun mirası kime kaldiysa onun tarafindan devam ettirilir

(Cic. leg. 2,48).

Her ne kadar Cicero ev kültlerinin uygulanmasındaki devamlılığı savunsa da özellikle ritüellerin uygulama yetkisinin rahiplerde olduğunu hatırlatmakta, otoritenin kimin olduğu vurgusunu böylece yapmaktadır. Ayrıca metinin başlangıcındaki "Bu haklar rahiplerin vekaleti sayesinde korunmakta" hatırlatması ile de devletin içinde kabul görmüş kültlerin evlerde ritüellerle yaşatılmasının istendiği anlaşılmaktadır.

$\mathrm{Bu}$ korumacı kontrol sisteminin arka planında yabancı kültlerin devlet kültlerine karıştırılmaması isteği yatmaktadır. Yabancı kültler, özellikle Doğu'dan Roma'ya gelen ve ev içlerindeki ritüellere yansımaya başlayanlar olmalıdır. Öncelikle Roma idaresinin hiçbir şekilde istemeyeceği kültler olarak Doğu'nun gizem dinlerini düşünmek mümkündür. 
Dionysos (Bacchus) kültündeki kendinden geçmiş, kontrol dişı ritüeller bunun bir örneği olabilir. Cicero da yukarıdaki söylemi ile yabancı kültlere ait ritüelleri bir tehdit olarak düşündüğünden, rahiplerin vekaletlerinin koruyuculuğunu öngörmekte; böylece muteber sayılan kültik uygulamaların güvence altında tutulmasını amaçlamaktadır.

Bu tehdit durumunu anlatan bir diğer kaynak da tarihçi Livius'tur. Onun 39. kitabındaki anlatıma göre; Consul Spurius Postumius Albinus, Yunanistan'dan Roma'ya gelen Bacchus kültünün ve ritüellerinin soruşturmasını yapmıştır. Bacchus kültünün yayılması, Etruria’da yaşamış olan Yunanlı bir din adamından kaynaklanmakta; ardından bu kişinin Roma'ya dönmesi ile burada gece ayinleri ile takipçiler araması ile yayılmaya başlamaktadır (Livius, $\mathrm{Ab}$ urbe condita 39, 8). Başlangıçta çok az kişinin bu ritüellere katılmasına rağmen, bu gizemli ritüllerin şarap ve cinselliği de kapsaması nedeniyle üyelerinin sayısı gitgide artmıştır. $\mathrm{Bu}$ kontrolsüz ritüeller daha sonra kamu düzenini bozmaya kadar gitmiş ve suç oranları bu ritüeller nedeniyle artmaya başlamıştır. Özellikle toplum tarafından hoş karşılanmayan birçok tabu, eşcinsellik, özgürlük, delilik, sapkınlık gibi kontrol dışı durumlar bu ritüeller içinde yapılmaya başlanır hale gelmiştir (Livius, Ab urbe condita 39, 13). Bunun üzerine Consul Spurius Postumius Albinus evlerde organize olan bu ritüellerin araştırılmasını sağlayarak, Roma düzenine bir tehdit olmasından dolayı sadece Roma şehrinde değil tüm ülke sınırları içinde Bacchus ritüellerini yasaklamıştır. Bacchus'a ait bütün kutsal alanlar tahrip edilmiş ve kullanılmasına engel olunmuştur. Bu soruşturma neticesinde yedi bin kişi tutuklanmış, kaçmak isteyenler ise kentin şehir kapılarında yakalanmıştır (Livius, Ab urbe condita 39, 19).

Livius'un naklettiği MÖ 186 yılında gerçekleşen bu olayı kanıtlayan epigrafik bir veri de bulunmaktadır (Resim 1). Bu, Viyana'daki Sanat Tarihi Müzesi'nde sergilenmekte olan yazıttır. Söz konusu metinde Bacchanalia hakkında hükümleri içeren senato kararı kaleme alınmaktadır (CIL 1, 581):

Quintus Marcius, Lucius [ve] Spurius Postumius'un oğlu, Lucius'un oğlu, konsüller olarak senatoyu Bellona Tapınağı'ndaki Ekim Nonen'ine [İ.Ö. 7. Ekim 186] çağırdı. Yazılı metinden sorumlu olanlar Marcus Claudius, Marcus'un oğlu, Lucius Valerius, Publius [ve] Quintus Minucius'un oğlu, Caius'un oğlu idi.

Bacchanalia şenlikleri ile ilgili olarak, [Roma ile] müttefikleri için şu bildiriyi ilan ettiler: Hiçbirinizin bir Bacchanalia için [bir yeri] olamaz. Bacchanal [için bir yere] ihtiyaç duyduğunu beyan eden kişiler varsa, Roma'ya şehir praetoruna gelmeliler ve dinlenmelerinden sonra senatomuz bu duruşmada en az 100 senatör bulundurarak bununla ilgili bir karara varmalıdır.

Şayet daha önceden şehir praetorunu ziyaret edip ondan buna ilişkin izin almamışsa, bir Roma vatandaşı, Latin veya müttefiklerden biri olup olmadığ 1 farketmeksizin, duruşmada en az 100 senatör varken Senato'nun onayı ile hiçkimsenin Bacchalar arasına karışmasına izin verilmez. [Buna senatörler] karar vermiştir.

Hiçbir erkeğin papaz/rahip/din adamı olmasına izin verilmez; hiçbir erkek ve hiçbir kadın yönetici olamaz; hiçbirinin ortak bir kasa/hesap kullanmasına izin verilmez; kadın ya 
da erkek ne [yönetici] bir yetkili ne de bir vekili, kimseye emir veremez. Bundan böyle yeminle, vaatle, sözleşmeyle ya da onayla birbirleriyle bağlanamazlar, birbirlerine karşılıklı söz veremezler. Şayet [daha önce] şehir praetoruna gitmemiş ve ona duruşmada en az 100 senatör varken Senato'nun onayı ile bu izni bildirmemişse, hiçkimsenin ritüelleri gizlice gerçekleştirmesine izin verilmez. Hiçkimse ritüelleri kamusal ya da özel alanlarda, hatta şehir dişında gerçekleştiremez. [Buna senatörler] karar vermiştir.

Kadın ve erkeklerin, toplamda beş kişiden fazla olmaları durumunda ritüel düzenlemelerine izin verilmemektedir. Yukarıda belirtildiği gibi, şehir praetorunun ya da senatonun [uygun] izni olmadan ikiden fazla erkek [ya da] üçten fazla kadın [ritüellere] katılamaz.

Bunu en az üç pazar gününde [halk] toplantısında ilan etmelisiniz ve senatonun aşağıdaki konuda kararını not almalısınız: Birisi yukarıda belirtilen hükümleri ihlal ederse, senatörlerin kararlaştırdığ 1 gibi ona sermaye süreci uygulanır. Ve siz bunu - ki senato böyle uygun görmüştür- bronz bir tabakaya kazımalısınız ve en iyi anlaşılabilecekleri yere yerleştirtmelisiniz. Ve Bakkhaların yerleri, şayet varsa - dini bir arka plan olması dışında yukarıda belirtildiği gibi bu evraklar size verildikten sonraki 10 gün içinde yok edilmelidir. [İkinci elden?] Teura bölgesinden [Terina?].

Bu senato kararı Roma'da ilk defa resmi bir kabulü olmayan, Roma'nın mos maiorum anlayışını tehdit eden devlet dışı bir külte karşı alınmış önemli bir hükmü yansıtmaktadır. Devletin kontrolü dışında var olan kültlere karşı bir emsal oluşturmaktadır. Her ne kadar evlerde gelişen ve yayılan Bacchus kültü doğrudan bir ev kültü olmasa da, ev kültlerine devletin bakışın anlaşılması açısından önem arz etmektedir. Şu açık bir şekilde anlaşılıyor ki kamusal olmayan kültlere karşı herhangi bir destekleme söz konusu değildir.

Bacchanalia ile ilgili olarak devlet otoritesinin sergilediği tutum, elbette ki kamu kültlerine dışında kalan bütün kültlerin tamamen yasaklandığg anlamına gelmemektedir. Aksine, Roma her ne kadar zorunlu kılmasa da resmi kültler için ritüel gerçekleştirilmesini beklemekte, ev içinde gelişen birçok külte ve onlarla bağlantılı ritüellere de müsaade etmektedir. Yasak Bacchanalia durumunda olduğu gibi ritüeller toplum düzenini yani mos maiorum anlayışına zarar vermeye başlarsa ortaya çıkmakta; bu aşamaya gelindiği takdirde toleransın ortadan kalkacağı anlamına gelmektedir.

\section{Evlerde Gerçekleştirilen Roma Festivalleri}

Romalılar, tanrılar ile iletişim halinde olmak, tanrıların huzurunu sağlamak için dua etmek ve kurban kesmek gerektiğini düşünürler. Bu tarz eylemlere firsat yaratmak için de belirli zamanları ritüel günleri olarak belirler. Roma dışında kalan koloniler ve eyalet şehirleri kendi dini takvimlerini oluşturmuştur. Bu takvimlerin günlerini o kentin yerel senatosu karar verir. Roma şehri için de bu pek farklı bir durum değildir. Roma'da takvimdeki ritüellerin uygulanmasına senato, festivallerin takvimdeki yerine ise pontifices kurumu karar vermektedir (Gordon, 2003, s.69).

Bu festivallerin uygulanması Romalılar için bir görev olması nedeniyle, pratiklere yönelik mekanlar oluşturulmuştur. Tapınaklar, kutsal alanlar, nişler ve ev içindeki ritüel alanları 
bu mekanların bazılarıdır. Her günün farklı bir amacı olması nedeniyle ritüel pratikleri de farklıdır. Ev ve aile ile ilgili ritüellerin gerçekleştirildiği yerler evlerde bulunan nişler ve bu uygulamalara ayrılan alanlardır. Bu çerçevede aile kültünü direkt ilgilendiren festivaller aşağıda açıklanarak sıralanmıştır.

\title{
Lemuria Festivali
}

Romalıların ölülerinin kötü-korkunç ruhlarını kendi evlerinden kovmak amacıyla yaptıkları festivaldir. Ailenin ölü üyelerinin ruhlarının Lemuria festivalinde, Mayıs ayının 9., 11., 13., günü evin içinde dolaştığına inanılardı (Akçay, 2017, s.145-147). En çok korkulan da genç ölülerdi, genç yaşta öldükleri için geride kalanlara kin besledikleri düşünülürdü. Ovidius her aile babasının evinde kendi başına gerçekleştirdiği ritüeli anlatır. Buna göre; aile babası hayaletleri defetmek için gece yarısı kalkar, evin içinde yalın ayak gezinir (yürürken) hayaletler yesin diye yere dokuz kara bakla firlatır, ailenin yaşayan üyeleri için verdiği bu kurtulmalık karşılığında hayaletlerin artık onları kaçırmayacağını ümit ederdi. Yerine getirdiği diğer ritüellerden sonra paterfamilias hayaletleri savmayı başarırdı (Ov. Fast. 5, 419). Ovidius, Fasti adlı eserinde 9 Mayıs’taki ritüelleri şu şekilde anlatmıştır:

\author{
Bununla birlikte eskiler o günlerde tapınakları kapattılar \\ şimdi Feralia zamanında kapattıklarını gördüğün gibi. \\ Ne dul kadınin ne de bakire kizın yanarcalarina uygundur \\ o zaman, evlenmiş olsa da olmaz evliliği uzun süreli. \\ Yine bu nedenle, ĕger etkiliyorsa seni atasözleri, \\ söyler durur halk "yoktur Mayıs ayında evlenmekten beteri (Ov. Fast. 5, 485-490).
}

Aynı Feralia Festivali'nde olduğu gibi yine bu ayda da düğünler ve çeşitli eğlenceler gerçekleştirilmez ve tapınaklar kapalı kalır.

kadim tapınmanın ayini yapılacak, ey geceye ait Lemuria,

o festival, sunular verecek ölmüşlerin suskun ruhlarına.

Yıl daha kısaydı, ne henüz biliyorlardı kutsal arınma törenlerini

ne de ayların önderiydin, ey çift yüzlü Ianus.

Yine de o zamana değin sönmüş kül yığınına getiriyorlardı hediyelerini

ve torun, gömülen dedesinin mezarına hürmet gösteriyordu (Ov. Fast. 5, 421-427).

9 Mayıs’taki Lemuria ölü kültü festivali kapsamında ritüellerin içeriği genel anlamda yukarıdaki dizelerde dile getirilmiştir. Ölenlerin yakınları sunular ile atalarının ruhlarını rahatlatılacağı inancı bu ritüellere hâkim olan inançtır.

ve ellerini pınar suyuyla tertemiz yıkadıktan sonra,

döner ve kara fasülyeleri alır önce

sonra yüzünü başka yöne çevirip atar;

ama atarken "bunları ben attyorum,

bu fasulyelerle hem kendimi hem de ailemi, 


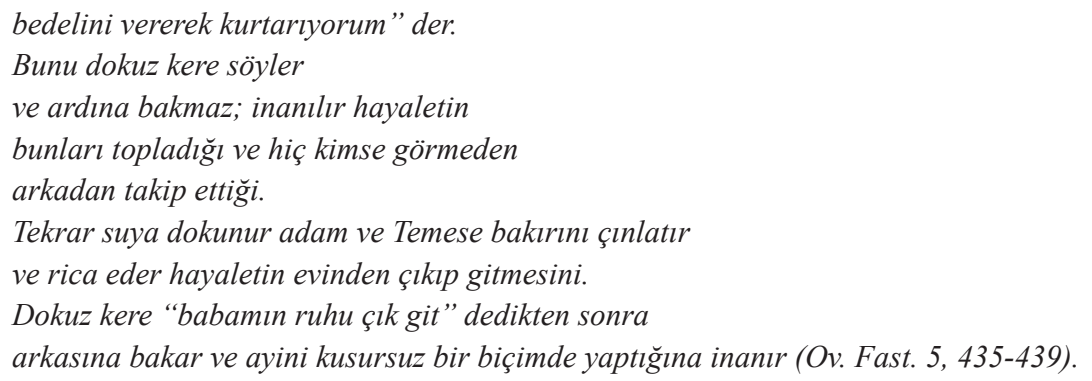

\section{Carista Festivali}

22 Şubat'ta gerçekleştirilen bu ritüel, Cara Cognatio olarak da bilinir. Parentalia, Feralia ve Carista festivalleri birbirleriyle yakından ilgilidir. 13 Şubat sabahı ölüyü yatıştırmak (placandis Manibus) için başlayan ritüeller 21 Şubat Feralia ile son bulur. Daha sonra Carista festivali başlar. Ölüler ile ilgili ritüeller gerçekleştirildikten sonra sıra yaşayan aile bireyleri için gerçekleştirilen ritüellere geçilmektedir. Bu ritüelin adı değerli akraba anlamına gelen cari'den türetilmiştir. Concordia ya da Carista onuruna gerçekleştirilir. $\mathrm{Bu}$ festival zamanında aile üyeleri evde toplanır ve herkesin katkı sağlayarak yapılan yemek birlikte yenir. Daha sonra aile tanrılarına (socios deos) kurban ritüeli gerçekleştirilip, ailenin iyi niyetleri dile getirilir. Kaba ve aç gözlü akrabalar ise bu ritüellerden çıkarılırdı (Scullard, 1981, s.74). Aile tanrıları (Ovidius Fasti adlı eserinde bu festivalden şöyle bahsetmiştir.

Aziz akrabalar ertesi günü Caristia olarak adlandırdılar
ve tanışmaya geldi akraba topluluğu aile tanrılarıyla.
Kuşkusuz mezarların ve göçüp gitmiş akrabaların ardından
Hoş bir şeydir yüzümüzü hemen yaşayanlara çevirmek
ve kaybedilen onca kişiden sonra soydan geriye ne kaldıysa
saymak ve akrabalık derecesini saptama (Ovid., Fasti, 2, 620).

Ovidius'tan da anlaşıldığı üzere akrabalar ile birliğin sağlanması için aile tanrılarına evde ritüeller gerçekleştirilmektedir. Ölü ruhlar için gerçekleştirilen ritüellerden sonra kalan akrabalar ile birlik içinde yaşama arzusu bu inancın temelidir.

\section{Compitalien Festivali}

Compitum (pl. compita) dört yol ağzı, kavşak anlamına gelmektedir. Bu alanlarda yılın belirli günlerinde toplanılır ve her katılanın kendine ait ritüel nişlerine (lares compitales) ritüeller gerçekleştirilirdi. Roma' da Augustus dönemine ait Lares'e adanmış Compitum Acili isimli küçük bir tapınak bulunmaktadır (Henner, 1988, s.398-400). Bu kült uygulamalarına Compitalia denmektedir. Bu ritüeller daha önceleri köylüler tarafından gerçekleştirilen Aralık sonu-Ocak başında kutlanan kış festivalleridir. Bu zamanlarda aileler buluşur, birlikte yemek yenir ve şarap içilirdi. Compitalia’nın bir önceki ve sonrasındaki gece aile bireyleri evdeki 
kült nişine yün bebekler asar, köleler ise yünden toplar yerleştirirlerdi. Kurbanlar sunulur ve aynı zamanda aile fertleri arasında oyunlar oynanırdı.

$\mathrm{Bu}$ festival aynı zamanda şehirlerde, insula'ların birleştiği kavşaklarda yer alan ritüel alanlarında gerçekleştirilirdi. Daha sonraki dönemlerde şehirlerde kutlanan bir festival haline gelen bu ritüeller özellikle görevliler ve köleler arasında yoğun bir şekilde benimsenmiştir.

\section{Evin Koruyucu Kültleri}

\section{Genius}

MS 3. yüzyılda yaşamış Roma yazarı Censorinus, ev kültlerinden biri olan Genius'u açıklamıştır (Censorinus, De Dei Natale 3.1, 5):

Genius, herkesin doğar doğmaz korumasında yaşadığ tanrıdır. Bizim meydana getirilmemizle ilgilenmesinden, kendisi de bizimle ayn zamanda meydana getirildiğinden, ya da bizi doğurulan olarak kabul edip koruduğundan dolayı "Genius" adını geno (meydana getirmek/çocuk yapmak/üremek)'dan alır.

Roma inancinda Genius, her insanda ya da bir yerde var olan ilahi bir ruh, ya da koruyucu tanrıdır. Doğumda, üremede evlilik yatağında (lectus genialis) ve yaşamla ilgili her aşamada geçerli olan koruyucu külttür (Turcan, 1998, s.29). Genius, insanı izleyen ruhsal bir varlıktır. Animizm anlayışı ile üretildiği ve devam ettirildiği konusunda görüşler bulunmaktadır ettirildiği konusunda görüşler bulunmaktadır (Turcan, 1998, s.29; Latte, 1960, s.104). Her insanda bir Genius'un var olduğuna inanılmakta ve doğum günlerinde çeşitli ritüeller gerçekleştirilmektedir. Ancak Genius'un sadece erkeklerde olduğu ve kadınlarda ise Iuno'nun aynı işleve sahip olduğu da söylenmektedir (Fox, 1916, s.291).

Paterfamilias bütün ailenin Genius'una ritüeller gerçekleştirme görevine sahiptir (Schilling, 1978, s.54). Doğum günleri Genius için en önemli ritüellerin yapıldığı günler olup, saygının bir sembolü olarak ritüellerin başlangıcında ritüellere katılanların alnına dokunulmakta, ev süslenmekte, Genius için kurban ritüeli gerçekleştirilmektedir. Genellikle Genius, (Resim 2) toga (togatus) ve başörtüsü (capite velato) giymiş, elinde bereket boynuzu (cornucopia) ve libasyon kabı (patera) tutmuş şekilde betimlenmektedir. Onun simgelerinden birisi de yılandır (Maharam, 1998, s.915).

Genius kişinin koruyucu ruhu olmasının yanında olayların ve toplumların da koruyucusu olabilmektedir. Bunun en önemli örneği olarak Roma şehrinin koruyucu ruhunun genius urbis Romae olması verilebilir. Roma toplumunun Genius'u genius populi Romani ve bir yerin koruyucu ruhu genius loci olarak adlandırılmaktadır (Lewis-Short, 2009). Daha sonra bu kavramlardan imparatorun koruyucusu anlamına gelen Genius Augusti inancı oluşturmuş, bu aynı zamanda Roma'daki imparatorluk kültünün temelleri olarak düşünülmüştür (Duncan, 2014, s.47-60). 
Genius loci yerleşimler, şehirler, meydanlar, binalar veya bu binalar içindeki bireysel odalar tapınaklar, tiyatrolar gibi alanların koruyucusudur. Bu koruyucu ruh görsel anlamda da betimlenmiştir. İngiltere'de Kuzey Wiltshire'da bulunan 13. yüzyıla ait St. Giles kilisesinin güney duvarında bir devşirme Roma kabartması üzerinde Genius loci betimlenmektedir (Resim 3). Tasvirin sağ elinde yılanlı bir asa, sol elinde ise cornucopia bulunmaktadır Toynbee, 1978, s.330). Hollanda'daki Nijmegen'deki Het Valkhof Müzesi'ndeki bir adak stelinin yazıtında (Resim 4); "I(upiter) O(ptimus) M(aximus) Genius loci'ye Gaius Candidinius Sanctus tarafindan atfedilmiştir” ifadesi yer almaktadır (CIL XIII, 8719).

Roma toplumunun koruyucu ruhu olan Genius populi Romani kültü arkeolojik açıdan da kanıtlanabilir niteliktedir. Napoli Ulusal Arkeoloji Müzesi’nde Farnese Koleksiyonunda yer alan heykel Genius populi Romani kavramının görünen örneklerindendir (Resim 5). Aynı zamanda sikkeler üzerindeki betimlemelerde de Genius ikonografisi kullanılmıştır. Örneğin MÖ 76-75 yıllarına tarihlenen bir denarius'un ön yüzünde üstte G.P.R harfleri ve altında da Genius büstü görülür (Resim 6). G.P.R harfleri genius populi Romani teriminin baş harfleridir. Sadece Roma toplumunun değil bu inanca sahip farklı etnik yapılar da bu kültü benimsemiştir. Örneğin İmparator Aurelianus dönemine ait, MS 270 yılına tarihlenen Siscia baskılı bir antoninianus'un ön yüzünde imparator büstü, arka yüzünde ise patera ve cournicopia tutan Genius bulunmakta, figürün üstünde de Illyrialıların Genius'u anlamı taşıyan GENIUS ILLVR yazmaktadır (RIC, 223) İki sikke bu kültün uzun süre kullanıldığını gösteren önemli bir kanıt olarak dikkati çekmektedir (Resim 7).

\section{Lares}

Etrüsk kökenli bir sözcük olan Lar, “soylu” demektir. Tanrı Mercurius ile Lara'nın çocukları Lar'lar ikiz erkek kardeştirler. Aileye ve kamuya özel olmak üzere iki çeşit Lares vardır. Aile Lar'ları koruyucu ev tanrılarıdır ve kamunun Lar'ları urbani/praestites adıyla kentleri, rustici adıyla kırsal alanları, compitales adıyla üç yol ağızlarını, marini adıyla denizleri korumaktadırlar.

Lares, Genius kültü yakından bağlantılı bir külttür. Tasvir sanatında başlangıçta tek figürlü bir personifikasyon ile olarak betimlenmekteyken, daha sonraki dönemlerde iki figür şeklinde betimlenmiştir. Kökleri Roma geleneğine dayanması rağmen başlangıcının ne olduğuna dair bilgi bulunmamaktadır (Dessau, 1994, s.806). Lares, Genellikle ölen kişilerin ruhu, tarla, çiftlik ve evlerin koruyucu tanrısı olarak betimlenmektedir. Lares'e dair ritüeller hem özel hem de kamunun resmi alanlarında gerçekleştirilmektedir. Evlerin belirli alanlarında Lares'e ait ritüel alanları (lar familiaris) bulunmaktadır.

Komedya yazarı Titus Maccius Plautus'un bir eserinde Lares'ten bahseder (Plaut. aul. prol. 1-5). 


\begin{abstract}
Böylece kimse, kim olduğumu böyle söylemeyecek.
Ben kusaca buyum: Ben burada bu evin koruyucu [lar familiaris] ruhuyum,

Benim dışarı çıktığımı/adım attığımı gördüğ̈̈nüz evin.

Bu eve yllardır sahibim ve onu koruyorum, şimdiyse

Babanın ve büyük babanın artık şimdiki beyefendinin0.
\end{abstract}

Lares sözcüğü bazı zamanlarda ev ile eş anlamlı olarak da kullanılmıştır. Bu anlamı ile özellikle ev halkının toplandığı, evin ocağının olduğu yer, genellikle Lares için ritüel gerçekleştirilen alanı tanımlamaktadır. Taşınmalarda veya seyahatlerde dahi Lares'e ait ritüel nesneleri gidilen yere götürülmektedir (Dessau, 1994, s.816). Evlerde Lares kültüne ait ritüeller lararium denen sunaklar ile yapılmakta, larariumlarda nişin içine pişmiş toprak figürinler yerleştirilerek ritüeller gerçekleştirilmektedir (Mastrocinque, 1999, s.1149). Bu nişler genellikle evin yatak odasında, mutfakta ya da atriumda bulunmaktadır (Turcan, 1998, s.18). Ritüeller esnasında sadece aile üyeleri değil aynı zamanda evin bir sakini olarak köleler de yapılan uygulamalara dahil olmaktadır.

Cato'ya göre ritüeller ilk önce paterfamilias'in Lares'i selamlaması ile başlamakta ve daha sonra kurban kesilmektedir. Aynı ritüeller evin dışında yol kavşaklarında, sınırlarda, arazilerde de bir sunak aracılığı ile yapılmaktadır (Dessau, 1994, s.808). Lares kültüne ait yıllık ritüeller ürünlerin hasatından sonra da gerçekleştirilmekte ve buna da compitalia denilmektedir. Ancak bu ritüellerin belirli bir günü bulunmamaktadır (Orr, 1978, s.1565). Takvimde yer alan ritüel zamanlarında evin ocağından sorumlu paterfamilias'ın eşi ocağı süslemekte ve ritüele hazır hale getirmektedir (Cardauns, 2008, s.980). Ev halkının ve kölelerin katılması gereken yemek öncesi kurban ritüeli gerçekleştirilmekte, daha sonra kısa bir dua konuşması yapılmaktadır (Turcan, 1998, s.17). Kurban şekli çeşitlilik arz etmektedir. Tuz, üzüm bal peteği, koyun, domuz gibi yiyecek ürünleri ritüellerde kurban edilmektedir Kalan yiyecekler de ateşe atılarak Lares'e sunulmaktadır (Cardauns, 2008, s.980). Bu ritüeller doğum günü gibi önemli günlerde ve çocukluktan çıkma zamanlarında tekrarlanmaktadır.

\title{
Dii Penates
}

Dii Penates, evin içi anlamına gelen "penus" kelimesinden türetilmiştir. Genel olarak evin içinde dolaşan ruhlar olarak algılanmakta ve evi koruyan güç olarak düşünülmektedir. Buna göre dii penates, pratik anlamda kilerdeki yiyecek içecek, odun kömür gibi ev içi ihtiyaçları koruyan ruhtur (Linderski, 2000, s.514).

Romalı yazar Aulus Gellius tarafindan MS 2. yüzyılda yazılmış eserde meslektaşı ile yapmış olduğu sohbette "penus" kavramı açıklanmıştır (Weiss, 1992, s. 223).

Duyduğuma göre Q. Scaevola bu ifadeyi açılamak için her şeyi kelimesi kelimesine sordurtmuştur: "penus (yiyecek stoğu) yenilebilir veya içilebilir her şey anlamina gelir (quod esculentum aut poculentum est)." "Mucius'un diğer ifadesine göre, ihtiyaçlardan 
satın alınılarak evin beyefendileri için, ya da evin hanımı için ya da çocukları için ve onu ve çocukları çevreleyen (ya da herkes için çalışan) hizmetkar olmayanlar için hazırda bulundurulan her şey penus ile anlatılmak istenen şey olmalıdır. Çünkü öğle ve akşam yemeklerinde günlük kullanım için satın alınan ve hazırlanan yiyecek ve içecekler penus olarak geçmez aksine daha ziyade uzun süre saklanmak için toplanan ve kilitlenen ve bu nedenle günlük kullanım için orada bulunmayan (tabiri caizse elden ağıza), ancak evin en derinlerinde saklı tutulan her şey penus olarak adlandırllır.

Lares ve di penates başlangıçta birbirinden çok farklı iki kült olmasına rağmen daha sonraki dönemlerde birbiriyle benzer kültler olarak anılmıştır. Ancak lares ve dii penates arasındaki en büyük fark, kölelerin kendilerine ait dii penates kültü bulunmamasıdır. Ancak lares ritüellerine bütün ev halkının katılması beklenmektedir. Lares babaların tanrısı (patrii di) ve Roma vatandaşlarının kültüdür. Lares daha çok ölen ataların tanrısı olarak algılandığı için daha sistematik bir düzen içermektedir. Ancak di penates'e dair ritüellerin ne zaman gerçekleştirildiği tam olarak bilinmemektedir (Weinstock, 1937, s.423-425).

Dii penates ritüelleri ailenin toplu bir şekilde yenilen yemeklerinde icra edilmektedir. Ayrıca libasyon sunusu patera'ya konularak üzerine tuz ve un serpilmiş daha sonra ocağa atılarak ritüel gerçekleştirilmiştir. Aynı zamanda lares kültünde olduğu gibi dii penates ritüellerinde de figürinler de ritüeller esnasında kullanılmaktadır. Evin taşınması ya da kısa süreli seyahatlerde de bu figürinler beraberinde götürülmektedir.

Dii penates, her ne kadar ev içi ritüeli gibi görünse de kamusal kabul görmüş, Roma toplumunu koruması için "publici penates populi romani quiritium" ritüeli oluşturulmuş, cumhuriyet döneminin bitişi ile "penates publici" olarak adlandırılmıştır (Linderski, 2000, s.515).

\section{Evlerdeki Ritüel Alanları}

Roma evlerinde sadece ritüel yapılması için ayrılan mekanlar çok ender görülmektedir (Rüpke, 2016, s.225-233). Buna karşıllk, evin odalarının sahip oldukları işlevlere uygun ritüeller uygulanmaktadır. Örneğin mutfak bölümünde yemekle ilgili ritüeller, mekan ritüele uygun bir hale getirilerek gerçekleştirilmektedir.

Evlerdeki ritüel alanlarının belirlenmesine en iyi örnekler Pompeii'de konutlarda tespit edilmiş̧ir. Kentte Regio $I V$ 'deki evlerin buluntuları arasında kült nişleri ve sunaklar vardır. Ritüel alanları olarak mutfak, peristylium ve atrium bölümleri değerlendirilmiştir. Atrium'u da cubicula, alae veya tablina odalarına ritüel nişleri yerleştirilmiştir. Bunun dışında evlerin doğrudan girişte yer alan odaları, avluların geniş açık alanları, koridorları, hamamları ve tuvaletlerinde herhangi bir şekilde ritüel uygulamasına ait bir arkeolojik veri bulunamamaktadır. Genel bir tercih olarak evin arka ve orta bölümleri ev kültü için 
değerlendirilmiş, hanenin en çok kullanıldığ 1 alanlarda yani mutfak ve yatak odası bölümlerinde kült pratikleri uygulanmıştır (Wallace, 1994, s.143).

Roma evlerinin girişinden geçildikten sonra atrium'a uzanan dar bir koridora varılır (fauces). Bu bölümdeki kültik uygulamaları antik literatür detaylı bir şekilde açıklamaktadır. Kapı ve kapı eşiği Hermes, Plutos, Dionysos, Athena, Hekataia, Silvanus, Herakles ve Liber gibi tanrılarla ilişkilendirilmiştir (Herter, Hoheisel ve Brakman, 1985, s. 777-780). Özellikle çocukların doğum günlerinde kapılar, eşikler çiçeklerle süslenmekte ve çocukların arınması anlamında kurbanlar kesilmektedir. Bu kurbanlar doğum tanrıları Picumnus ve Pilumnus'a adanmakta ve Iuno ve Hercules için de bir sofra hazırlanmaktadır (Turcan, 1998, s.18-21).

Roma evlerinde kültik uygulamaların, çeşitli ritüellerin hayata geçirilmesinde larariumlar önemli role sahip bulunmaktadır. Lararium terimi ilk kez Roma İmparatorluk Dönemi'nde ortaya çıkmıştır. Bunlar, nişler küçük bir tapınak cephesine (aedicula) benzetilerek tasarlanan ve dekore edilen nişlerdir. Başlangıçta Lararium'ların kurban ritüeli için kurgulandığ söylenmektedir (Fröhlich, 1991, s.21). Lararium'ların dekorasyonunda genellikle bazı ikonografiler yer almakta; bunlar ev tanrıları ya da ev halkının atalarının tasvirlerinden oluşmaktadır. Bunun yanında ölü kültü ile ilgili ritüeller de larariumların bulunduğu alanlarda yapılmaktadır. Özellikle cenaze sonrasındaki manevi arınma ritüeli larariumlarda gerçekleştirilmektedir (Rüpke, 2001, s102-104).

Roma ev mimarisinde peristiller önemli yapı birimleri olarak hem binanın büyük bir bölümünü kaplamakta hem de yaşam ve eğlence alanları olarak kullanılmaktadırlar. Evin süs havuzları avlularda yer almakta ve misafir ağırlaması için ideal bir ortam sağlamaktadır. $\mathrm{Bu}$ bölümde genellikle ritüellerin gerçekleştirildiği lararium'lar da yer almaktadırlar. Buna en güzel örnek Pompeii' deki Casa degli Amorini Dorati'dir (Resim 8). Bu evin hem atriumunda hem de peristylinde larariumlar bulunmaktadır. Peristyliumdaki larariumda Trias, Merkur, Lares tanrılarının bronz heykelcikleri bulunmuştur (Lipka, 2006, s.328-339).

Roma konutunda ev kültleri ile ilgili ritüel uygulamalarının yapıldığı nişlerin yer aldığı bir diğer yer de mutfaklardır. Mutfaklar bir evin bereketinin hayata döküldüğü alanlar olduğu için burada çeşitli ritüellerin yapılmış olması gayet normal karşılanmaktadır. Genellikle ocak bir ritüel yeri gibi kullanılmakta; ocağa bırakılan sunular, tanrının payının verilmesi gibi ritüeller mutfağı ritüel alanına dönüştürmektedir. Pompeii'de Casa di Cenaculo evinin mutfağında (Resim 9) ve Casa dei Vettii evinin de mutfakla bitişik servis bölümünde (Resim 10) birer lararium tespit edilmiş olması evlerin mutfaklarında gerçekleştirilen ritüelleri yansitmaktadır (Lipka, 2006, s.328).

Genel olarak bir evin peristylium, atrium ya da mutfağında görülen larariumlar bazen de evin yan odalarında da görülebilmektedir. Buna en güzel örnek Ephesos’taki "Yamaç 
Evi 2"dir (Resim 11). İşlevi tam olarak bilinmeyen bir odanın kuzey duvarında yılan betimi görülmektedir. Bunun da Genius loci ile bağlantılı olacağı düşünülmektedir (Quatember, 2003, s.171-175).

Cubiculum yani evin yatak odası olarak tanımlanabilecek özel alanda larariumlar bulunabilmektedir. Pratik manada günün sonu ve güne başlama alanı olarak düşünülebilecek yer olan yatak odalarında bir ritüelin gerçekleştirilmesi normaldir. Pompeii'deki Casa del Larario Fiorito evinde cubiculum'da bir lararium bulunmaktadır (Resim 12).

Bazı bilim insanları cubilicum'u yerel ve kişisel olarak gerçekleştirilen ritüellerin merkezi olarak kabul etmektedirler (Sessa, 2007, s.203). Mezar odalarını da sonsuzluk uykusuna dalınan birer mekân olarak değerlendirmek olasıdır.

Doğu Dağlık Kilikia'nın önde gelen merkezlerinden olan Olba'da (Mersin'in Silifke ilçesine bağlı Örenköy) yapılan çalışmalarda tespit edilen kaya mezarının ana mekanının bu anlayışla tasarlanarak, mezar odasındaki alınlıklı nişin bir lararium olarak yapıldığı konusunda önerilerimiz bulunmaktadır:

Olba'da Doğu Vadisi tabanından yaklaşık 20 metre yükseklikte, cephe düzenlemesindeki Korinth düzeninde sütun ve anta başlıkları ile dikkati çeken tapınak cepheli kaya mezarı bulunmaktadır (Resim 13) ${ }^{2}$. Mezar vadiye yukarıdan bakan görkemli bir mimari cephe düzenlemesinde kemerli girişinin (arcus) her iki yanında yer alan birer cippus (mezar sunağ 1 ) dikkati çekmektedir. Kemerli girişin üstünde ise, tapınaklara öykünerek yapılmış bir cephe bulunmaktadır. Burada iki anta ucu ile iki bunların arasında iki sütun alçak kabartma şeklinde işlenmiştir. Mezar odasına giriş kemerli bir kapıdan (arcus) sağlanmaktadır (Resim 14). Mezar girişinin hemen kuzey tarafında arcosolium tipinde yapılmış bir mezar yeri vardır (Resim 15). Mezar odasına girişin hemen karşısında yer alan niş, mekânın önemli bir elemanıdır. Bunun tanrıya yönelimin bir göstergesi olarak naiskos tarzında yapılmış bir kült nişi bulunmaktadır (Resim 16). Nişin iki kenarında kaidesiz Dor düzeninde antalar bulunmaktadır. Bunlardan birinin başlı̆̆ı tahrip olmuştur. Başlıkların üstünde bir arşitrav bölümü için yer bırakılmış, onun üstüne de üçgen alınlık eklenmiştir. Mimari detaylar (anta başlıkları hariç) son derece derin ve belirgin olarak işlenmiştir. Nişin tabanından alınlığın uç kısmına kadarki boyu $0.87 \mathrm{~m}$, taban genişliği ise $0.58 \mathrm{~m}$ ölçülerindedir. Nişin tabanında mezara doğru yönelmeyen, derinleştikçe kısmen daralan 20 cm'lik bir oyuğu bulunmaktadır.

2 Söz konusu kaya mezarının tarihleme önerisi için bkz; Akçay, 2014, s.79-95; Akçay, 2018, s.174-176. 2003 yılında yapılan yüzey araştırması sırasında Erten tarafindan kaya mezarı detaylı bir şekilde çalışılmış ve çizimleri yaptırılmıştır. Erten, 2004, s.11-23. Tapınak cephelerinin alınlıklı ve sütunlu düzenlemelerine öykünerek oluşturulan mezar cepheleri Dağlik Kilikia'da görülmektedir. Bunlarda Yunan mimarisinin klasik düzenleri (Ion, Dor ve Korinth) kullanılmakta, basit kaya mezarlarına oranla sahibinin yüksek sosyal ve ekonomik düzeyini gösteren bir özeni yansıtmaktadırlar. Olba'da söz konusu Korinth düzenindeki cephe düzenlemesine sahip kaya mezarının yanında bir de Ion düzeninde cephesi olan kaya mezarı bulunmaktadır. 
$\mathrm{Bu}$ oyuk nişin sadece sembolik anlam taşımadığını, aynı zamanda ölü kültü ile ilgili bir işlevselliğe de sahip olduğunu göstermektedir. Bir alınlıkla taçlandırılan naiskos biçiminde işlenen nişin içindeki bu oyuğun içinde muhtemelen tapınım ile alakalı kurban sunusu ya da libasyon yapılmakta olduğu düşünülmektedir.

Tapınak cepheli kaya mezarı Olba'da geçerli ölü kültüne ilişkin önemli sonuçlar vermektedir. Roma dünyasında mezar, ölünün öteki dünya için evi olarak düşünülüp, tasarlanmaktadır. Roma dininde mezarlar, ölen kişi için "domus aeterna" yani sonsuz ev olarak kabul edilmektedir ${ }^{3}$. Heracleia Pontice'de bulunmuş bir mezar yazıtında mezarların en son ev olduğu açık bir şekilde belirtilmiştir (Şahin, 1975, s.294-295) (Resim 17).

...Insanların en son evi ve en son duvarı mezarlardir ve evlerden daha sadiktır bedenlere...

Olba'daki kaya mezarı dışında mezar odasında naikoslu nişlerin yer almasına başka örnekler de verilebilir. Mersin'de bulunan Şırşır Kalesi olarak adlandırılan alanda bazı kaya mezarları tespit edilmiştir. Bu kaya mezarların birinin içinde bir naiskoslu nişe rastlanmıştır. Nişin her iki kenarında plasterler, üstünde arşitrav, onun üstünde de akroterli alınlık bulunmaktadır. Arşitravda da TYPANNOC IN $\triangle E O Y C$ EחOIHCEN (Tyrannos Indeous yaptı) yazmaktadır (Söğüt, 2003, s.239-260).

$\mathrm{Bu}$ temel bilgiler 1şığında, mezarların içerisindeki ölü kültüne ilişkin bazı unsurların aslında evlerde görülen benzerleriyle ilgili olmaları mümkündür. Özellikle hem biçimsel hem de işlevsel anlamda Roma dünyası için mezar odasındaki naiskoslu nişler, Roma konutlarındaki lararium'lar niteliğinde olabilir. Olba'daki kaya mezarının tek kişiye ait olduğu mezar odasındaki sandukadan anlaşılmakta; mezarın açılıp aile fertleri tarafından tekrar kullanılması mümkün görünmemektedir. Bir daha açılmamak üzere kapatılan mezar odasındaki bütün detaylar, öteki dünya inancı ile ilişkili sayılmalı, ölen kişinin sonsuz yolculuğunda kendisini evinde hissetmesi amaçlanmış olmalıdır.

\section{Sonuç}

Romalıların tanıdığı tanrılarının yanında bir de kişileştirilmeyen kültleri de bulunmaktadır. Manevi fikirlerin de tapınıldığı Roma'da, farklı kültürlerin toplum içine sirayet etmesi Roma dinini, eklektik bir yapıya dönüştürmüş ve bir ritüeller dini haline getirmiştir. Bu çeşitliliğin en önemlilerinden aile içinde gelişen sacra privata olarak adlandırabileceğimiz aile kültleri ritüellerin gündelik olarak yapıldığı kurumlardandır. Devletin yönetilmesinde hayati öneme sahip aile içinde gelişen bu dini gelenek bazı dönemlerde Roma yönetimince kontrol altına alınmak istenmiştir. Bacchanalia gibi evlerde gelişen kültler kontrol dışına çıkmış ve Roma yönetimi buna karşı önlemler almıştır. 
Ritüellerin bir takvim çatısı altında toplandığı Roma festivallerinin bazılarında evlerde çeşitli dini pratikler gerçekleştirilmiştir. Bu festivallerin uygulanması Romalılar için bir görev olması nedeniyle, ritüellerin gerçekleştirilmesine yönelik mekanlar oluşturulmuştur. Tapınaklar, kutsal alanlar, nişlerin yanısıra ev içleri de bu ritüel alanları arasında yer almaktadır. Belirlenen her özel günün farklı bir amacı olduğundan, o güne özgü ritüel pratikleri de farklıdır. Ev ve aile ile ilgili ritüellerin gerçekleştirildiği yerler evlerde bulunan nişler ve bu uygulamalara ayrılan alanlardır.

$\mathrm{Bu}$ festivallerin başında Lemuria Festivali, Compitalien Festivali, Carista Festivali gelmektedir. Lemuria, Romalıların ölülerinin kötü-korkunç ruhlarını kendi evlerinden kovmak amacıyla yaptıkları festivaldir. Bu nedenle doğrudan Roma evi ile ilgilidir. Carista festivalinde, ölüler ile ilgili ritüeller gerçekleştirildikten sonra sıra yaşayan aile bireyleri için gerçekleştirilen ritüellere gelir. Bu festival zamanında aile üyeleri evde toplanır ve herkesin katkı sağlayarak yapılan yemek birlikte yenir. Daha sonra aile tanrılarına (socios deos) kurban ritüeli gerçekleştirilip, ailenin iyi niyetleri dile getirilir. Compitalien Festivalinde aileler buluşur, birlikte yemek yenir ve şarap içilirdi. Compitalia'nın bir önceki ve sonrasındaki gece aile bireyleri evdeki kült nişine yün bebekler asar, köleler ise yünden toplar yerleştirirlerdi. Kurbanlar sunulur ve aynı zamanda aile fertleri arasında oyunlar oynanırdı.

Ev içinde gerçekleştirilen ritüeller genellikle hanenin koruyucu kültlerine adanmıştır. Roma dini inancında Lares, Dii Penates, Genius en bilinen ev tanrılarıdır. Bu kültler aslında tanrıdan ziyade evlerin ve ailenin koruyucu ruhlarıdır. Bu kültlere dair ritüeller evlerin bazı bölümlerinde oluşturulan kült alanlarında yapılmıştır. Örneğin mutfak bölümünde yemekle ilgili ritüeller, mekân ritüele uygun bir hale getirilerek gerçekleştirilmektedir. Roma evlerinde kültik uygulamaların, çeşitli ritüellerin hayata geçirilmesinde larariumlar önemli role sahip bulunmaktadır. nişler küçük bir tapınak cephesine (aedicula) benzetilerek tasarlanan ve dekore edilen nişlerdir. Başlangıçta Lararium'ların kurban ritüeli için kurgulandığı söylenmektedir. Lararium'ların dekorasyonunda genellikle bazı ikonografiler yer almakta; bunlar ev tanrıları ya da ev halkının atalarının tasvirlerinden oluşmaktadır. Bunun yanında ölü kültü ile ilgili ritüeller de larariumların bulunduğu alanlarda yapılmaktadır. Özellikle cenaze sonrasındaki manevi arınma ritüeli larariumlarda gerçekleştirilmektedir. Cubiculum yani evin yatak odası olarak tanımlanabilecek özel alanda larariumlar bulunabilmektedir. Pratik manada günün sonu ve güne başlama alanı olarak düşünülebilecek yer olan yatak odalarında bir ritüelin gerçekleştirilmesi normaldir. Bazı bilim insanları cubilicum'u yerel ve kişisel olarak gerçekleştirilen ritüellerin merkezi olarak kabul etmektedirler. Mezar odalarını da sonsuzluk uykusuna dalınan birer mekân olarak değerlendirmek olasıdır.

Roma dininde mezarlar, ölen kişi için "domus aeterna" yani sonsuz ev olarak kabul edilmektedir. Doğu Dağlık Kilikia kentlerinden biri olan Olba’da yapılan çalışmalarda tespit 
edilen kaya mezarının ana mekanının bu anlayışla tasarlanarak, mezar odasındaki alınlıklı nişin de bir lararium olarak yapıldığı önerisini bilim dünyasına sunmaktayız.

\section{Kaynakça}

Akçay, T. (2014). Olba'daki Tapınak Cepheli Kaya Mezarı, Seleucia ad Calycadnum, IV, 79-94.

Akçay, T. (2017). Yunan ve Roma 'da Ölü Kültü, Ankara: Bilgin Kültür Sanat.

Akçay, T. (2018). Olba'da Ölü Kültü, Ankara: Bilgin Kültür Sanat.

Bendemann, R. (2011). Formen nichtöffentlicher Frömmigkeit bei Griechen und Römern, Weltauffassung Kult - Ethos, NTAK, 3, 224-229.

Cardauns, B. (2008). Lar (Lararium). Schöllgen Geurg u.a. (Hgg.). RAC 22 (pp. 978-989). Stuttgart: Anton Hiersemann..

Deissman, M. L. (1998). Familie IV. Griechenland und Rom, DNP, 4, 412-417.

Dessau, H. (1994). Lares. Kroll Wilhelm (Hg.). J. B. Metzler. RE 22 (1) (pp. 806-833). Stuttgart/Niemar: Anton Hiersemann.

Duncan, F. (2014). Augustus and the cult of the emperor, Studia Historica. Historia Antigua 32, 47-60.

Erten, E. (2004). Mersin, Silifke, Olba Yüzey Araştırması 2003, AST 22, (2) Cilt, 11-23.

Fox, W. S. (1916). The Mythology of All Races - Greek and Roman - Vol. I., Boston: Marshall Jones Company.

Fröhlich, T. (1991). Lararien- und Fassadenbilder in den Vesuvstädten: Untersuchungen zur "volkstümlichen" pompejanischen Malerei, Darmstadt: Verlag Phillip von Zabern in Wissenschaftliche Buchgesellschaft

Georges, K. E. (1902). Kleines Lateinisch-Deutsches und Deutsch-Lateinisches Handwörterbuch, Leipzig: Hahnsche Buchhandlung.

Gradel, I. (2002). Emperor Worship and Roman Religion, Oxford: Clarendon Press.

Gordon, R. (2003). From Republic to Principate: Priesthood Religion and Ideology. Ando, C. (Eds.), Roman Religion (pp. 62-84), London: Edinburgh University Press.

Herter, H., Hoheisel, K., \& Brakman, H. (1985). Haus I, Reallexicon für Antike und Christentum, 13, 770-801.

Henner, V. H. (1988). Das Compitum Acili. In Mathias Hofter (Hrsg.), Kaiser Augustus und die verlorene Republik. Eine Ausstellung im Martin-Gropius-Bau, Berlin, 7. Juni-14. August 1988 (pp. 398-400) Mainz, von Zabern.

Kaiser, M. (1965). Das römische Privatrecht. München: C. H. Beck.

Lattimore, R. M. (1962). Themes in Greek and Latin epitaphs. Urbana IL: University of Illinois Press.

Latte, K. (1960). Römische Religionsgeschichte, München: C. H. Beck.

Lewis, C. T., \& Short, C. (2009). genius. A Latin Dictionary. Perseus Digital Library, Tufts University.

Linderski, J. (2000). Penates (Di Penates), DNP, 9, 414-416.

Lipka, M. (2006). Notes on Pompeian Domestic Cults, Numen Vol. 53, (3), 327-358.

Maharam, W. A. (1998). Genius, DNP, 4, 915-917.

Mastrocinque, A. (1999). Laren, DNP, 6, 1147-1150.

Nilsson, M. P. (1992). Geschichte der griechischen Religion. München: C. H. Beck.

Orr, D. G. (1978). Roman Domestic Religion, ANRW, 16 (2), 1559-1591. 
Palagia, O. (1980). Euphranor, Monumenta Graeca et Romana 3, Leiden: E. J. Brill.

Rives, J. B. (2007). Religion in the Roman Empire. Oxford: Blackwell.

Rüpke, J. (2001). Die Religion der Römer, München: C. H. Beck.

Rüpke, J. (2016). Pantheon, München: C.H. Beck.

Schwabl, H. (1972). Zeus I. Halbband, Ziegler Konrad (Hg.). im: RE 2. Reihe. 19. (pp. 253-376). München: Druckenmüller Verlag.

Scullard, H. (1981). Festivals and Ceremonies in Roman Republic. London: Thames and Hudson Press.

Schilling, R. (1978). Genius, RAC 10, 51-83.

Sessa, K. (2007). Christianity and the Cubiculum: Spiritual Politics and Domestic Space in Late Antique Rome, Journal of Early Christian Studies 15, (2) 171-204.

Sjövall, H. (1931). Zeus im altgriechischen Hauskult, Lund: Hakan Ohlsson.

Söğüt, B. (2003). Dağlık Kilikia Bölgesi Mezar Nişleri, Olba, 7, 239-260.

Şahin, S. (1975). Das Grabmal des Pantomimen Krispos in Herakleia Pontike, Zeitschrift für Papyrologie und Epigraphik, 18, 293-297.

Toynbee, J. M. C. (1978). “Two Romano-British Genii”, In Britannia, Vol. 9, Society for the Promotion of Roman Studies (pp. 330). London: Cambridge University Press.

Turcan, R. (1998). The Gods of Ancient Rome. Religion in Everyday Life from Archaic to Imperial Times, New York: Routledge.

Quatember, U. (2003). Private Kulteinrichtungen im Hanghaus 2 in Ephesos, In B. Asamer - W. Wohlmayr (Hrsg.), Akten des 9. Österreichischen Archäologentages in Salzburg 2001 (pp.171-175), Wien, Phoibos Verlag.

Wachsmuth (1980). Aspekte des antiken mediterranen Hauskults, In Numen 27 (pp. 34-75), Van Voos Herma u. a. (Hgg.), Leiden, E. J. Brill. Waelkens, M. (1980). Das Totenhaus in Kleinasien, Antike Welt 4, 3-12.

Wallace, H. (1994). Houses and society in Pompeii and Herculaneum, New Jersey: Princeton University Press.

Weiss, F. (1992). Gellius, Aulus, Die Attischen Nächte. Band 1, Darmstadt: Wissenschaftliche Buchgesellschaft,.

Weinstock, S. (1937). Penates, RE 19, (1) 417-157. 


\section{RESIMMLER}

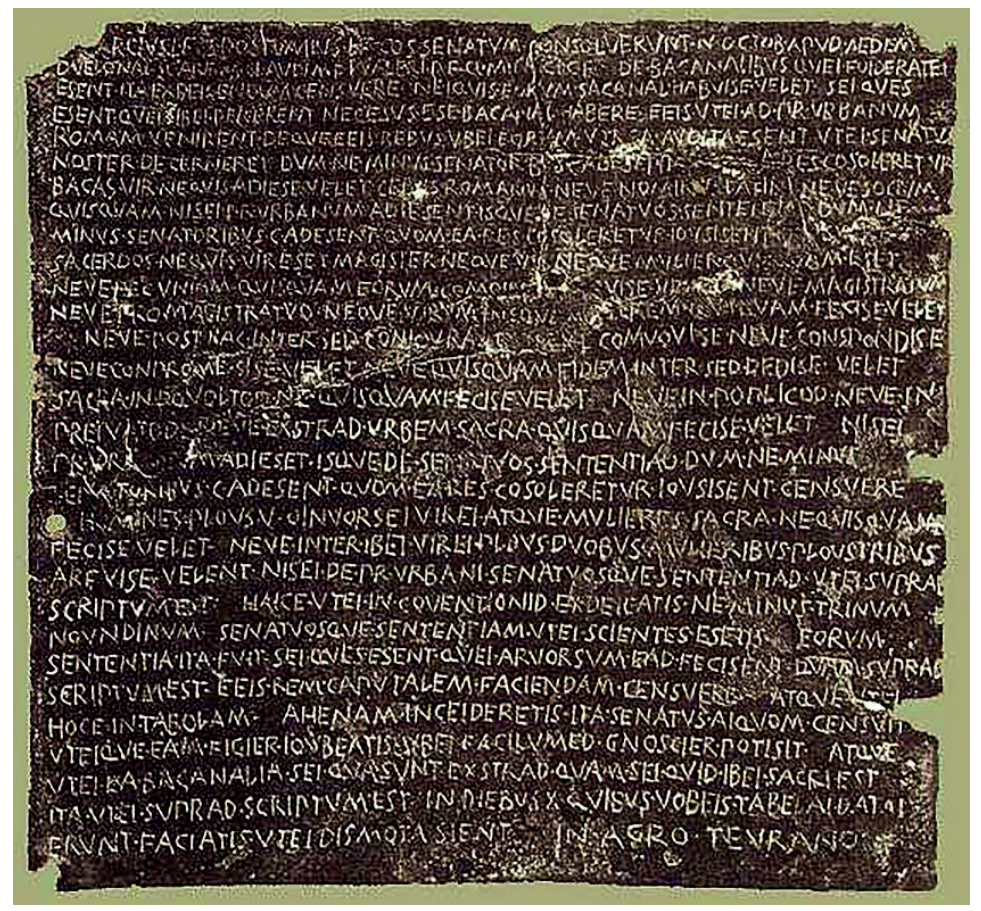

Resim 1. Bacchanalia hakkında hükümleri içeren yazıt. 


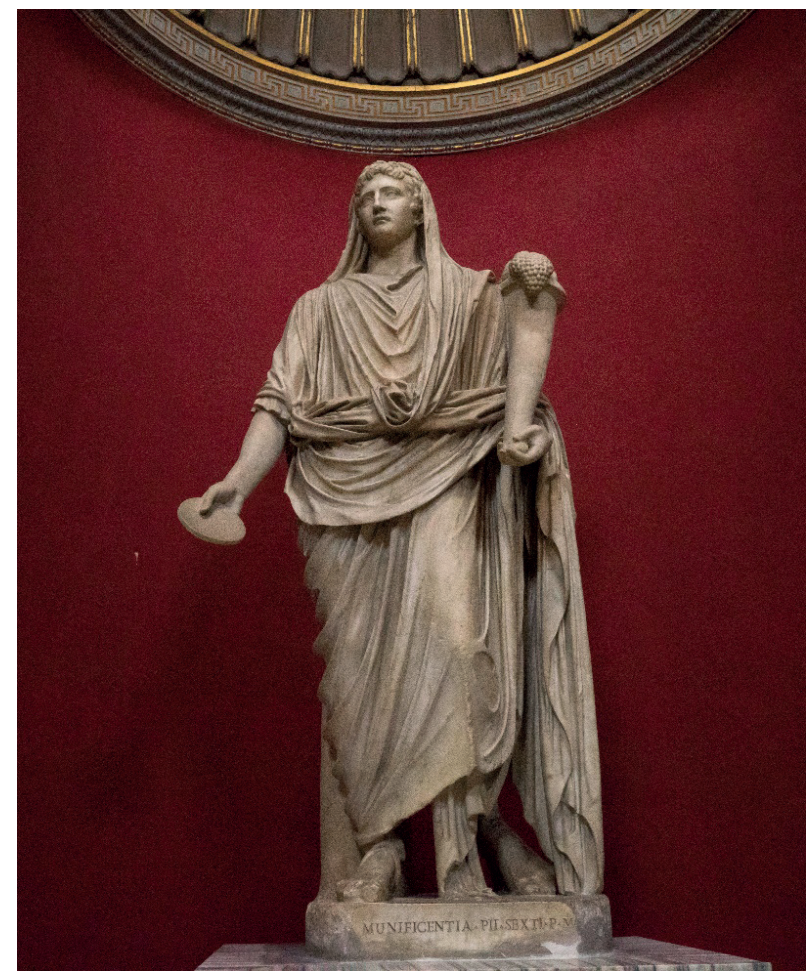

Resim 2. MS 1. yüzyıla ait Vatikan Müzesindeki Genius Heykeli.

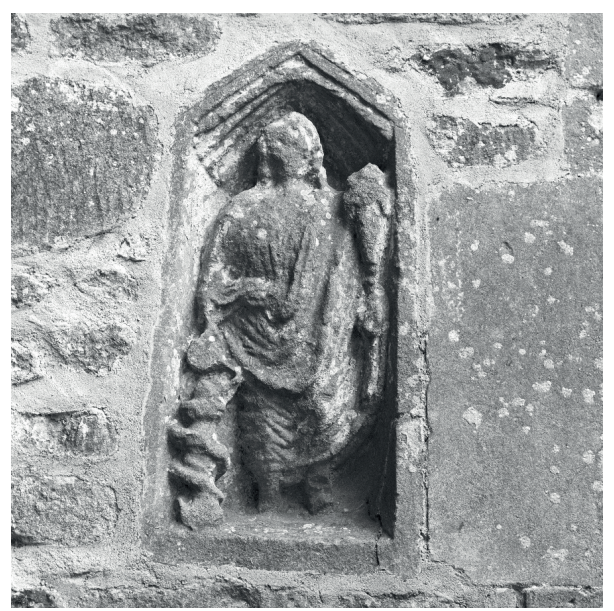

Resim 3. İngiltere'de Kuzey Wiltshire'da bulunan 13. yüzyıla ait St. Giles kilisesinin güney duvarındaki Genius Loci. 


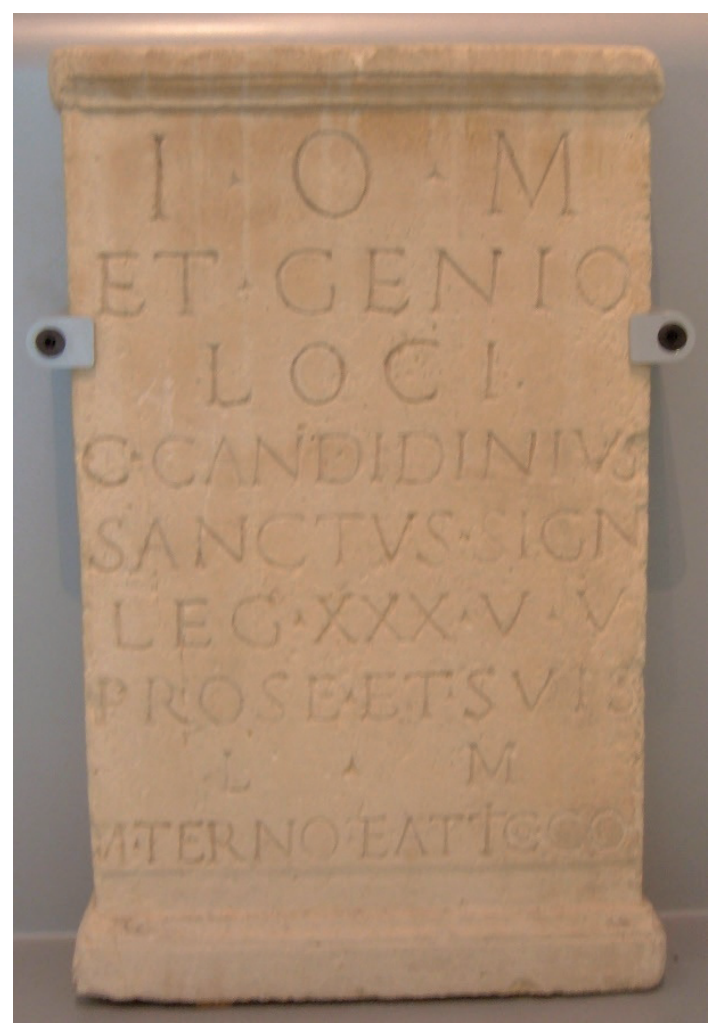

Resim 4. Hollanda'daki Nijmegen'deki Het Valkhof Müzesi’ndeki bir adak steli. 


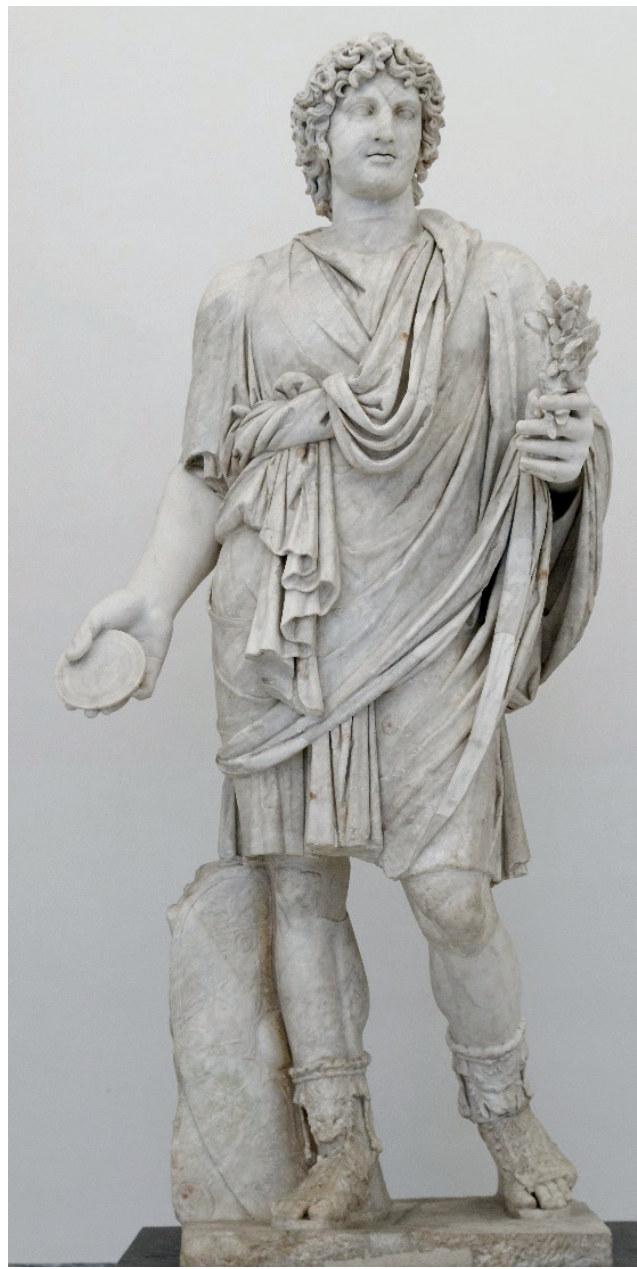

Resim 5. Napoli Ulusal Arkeoloji Müzesi'nde Farnese Koleksiyonunda yer alan Genius populi Romani Heykeli. 


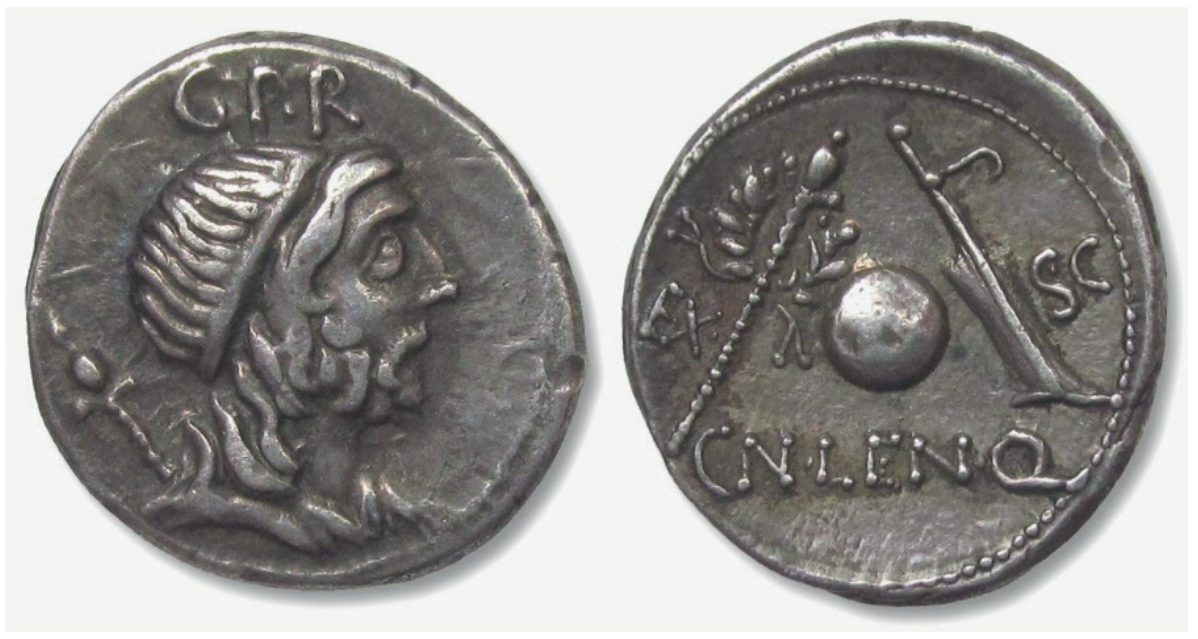

Resim 6. MÖ 76-75 yıllarına tarihlenen bir denarius.
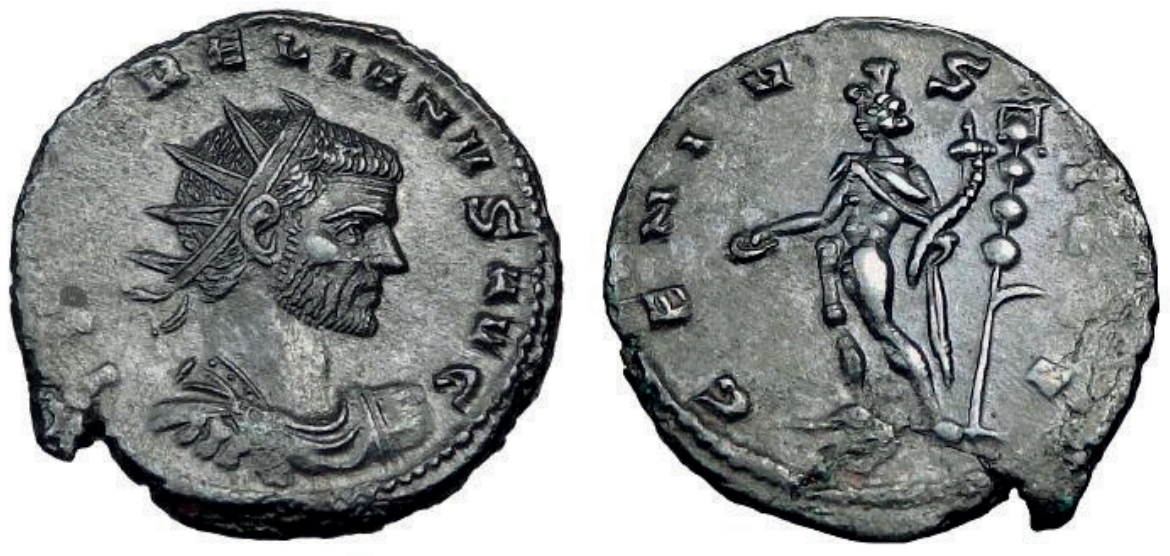

Resim 7. İmparator Aurelianus dönemine ait, MS 270 yılına tarihlenen Siscia bask1lı bir antoninianus. 


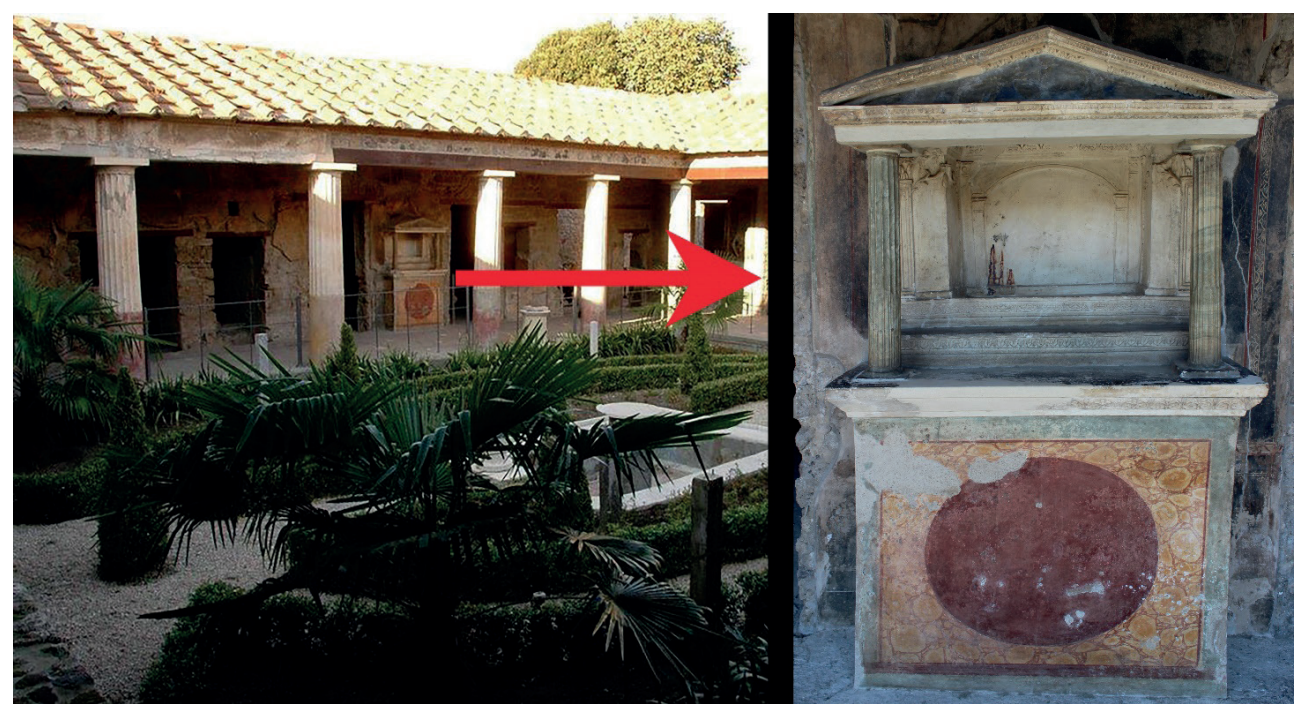

Resim 8. Pompeii'deki Casa degli Amorini Dorati evindeki lararium.

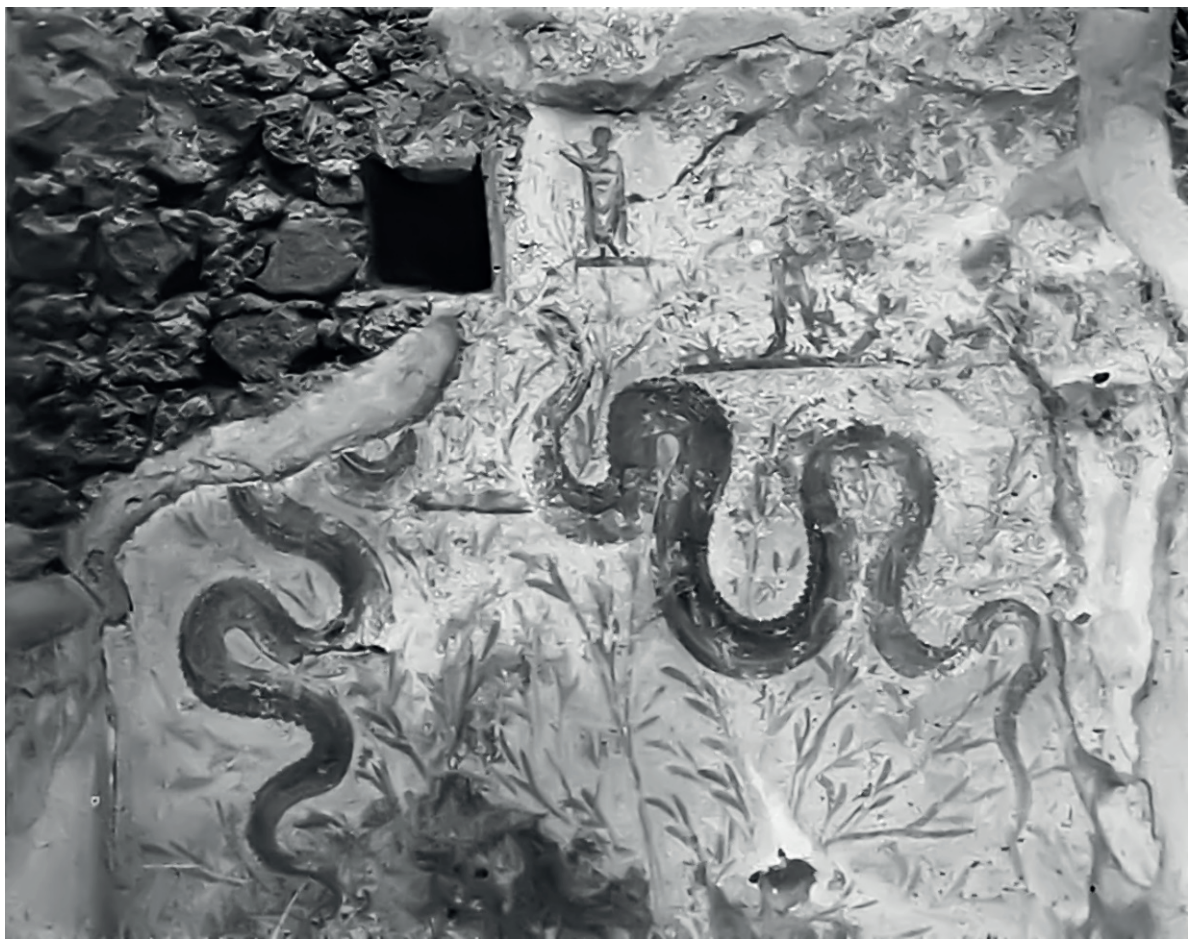

Resim 9. Pompeii'de Casa di Cenaculo evinin mutfağındaki lararium. 


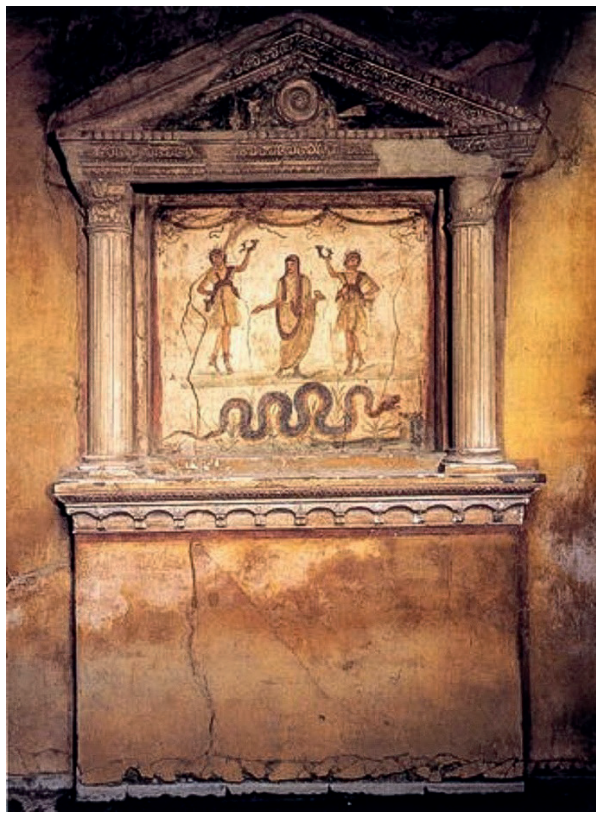

Resim 10. Casa dei Vettii evinin de mutfakla bitişik servis bölümündeki lararium.

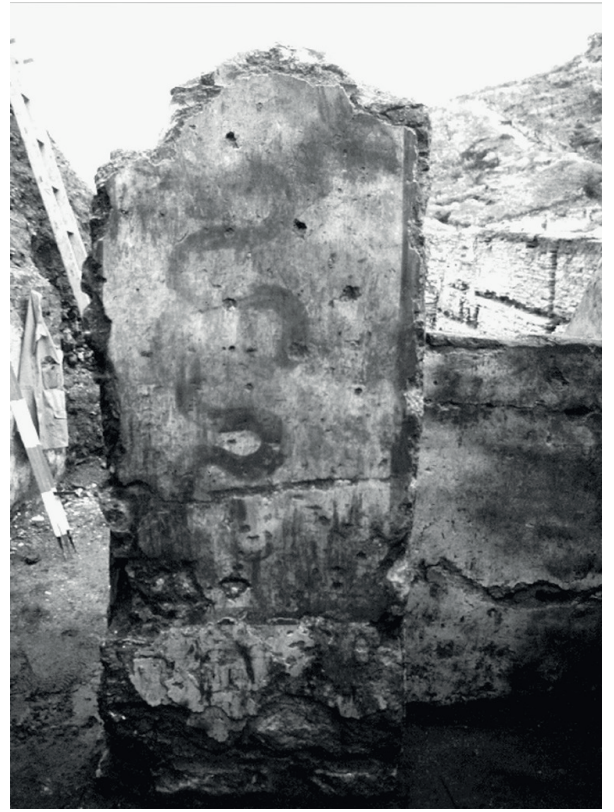

Resim 11. Ephesos’taki "Yamaç Evi 2" deki lararium 


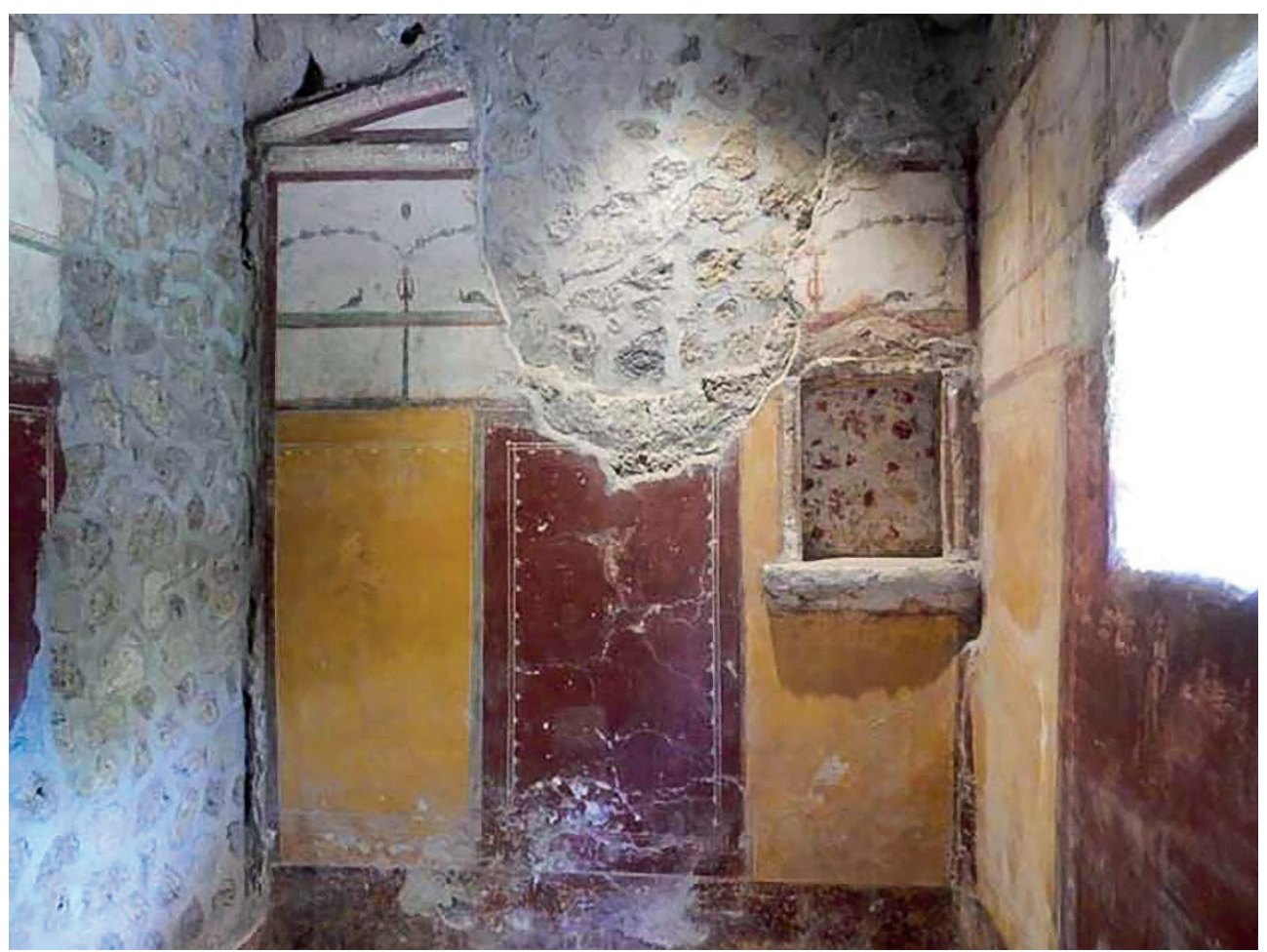

Resim 12. Pompeii'deki Casa del Larario Fiorito evinde cubiculum'daki lararium. 


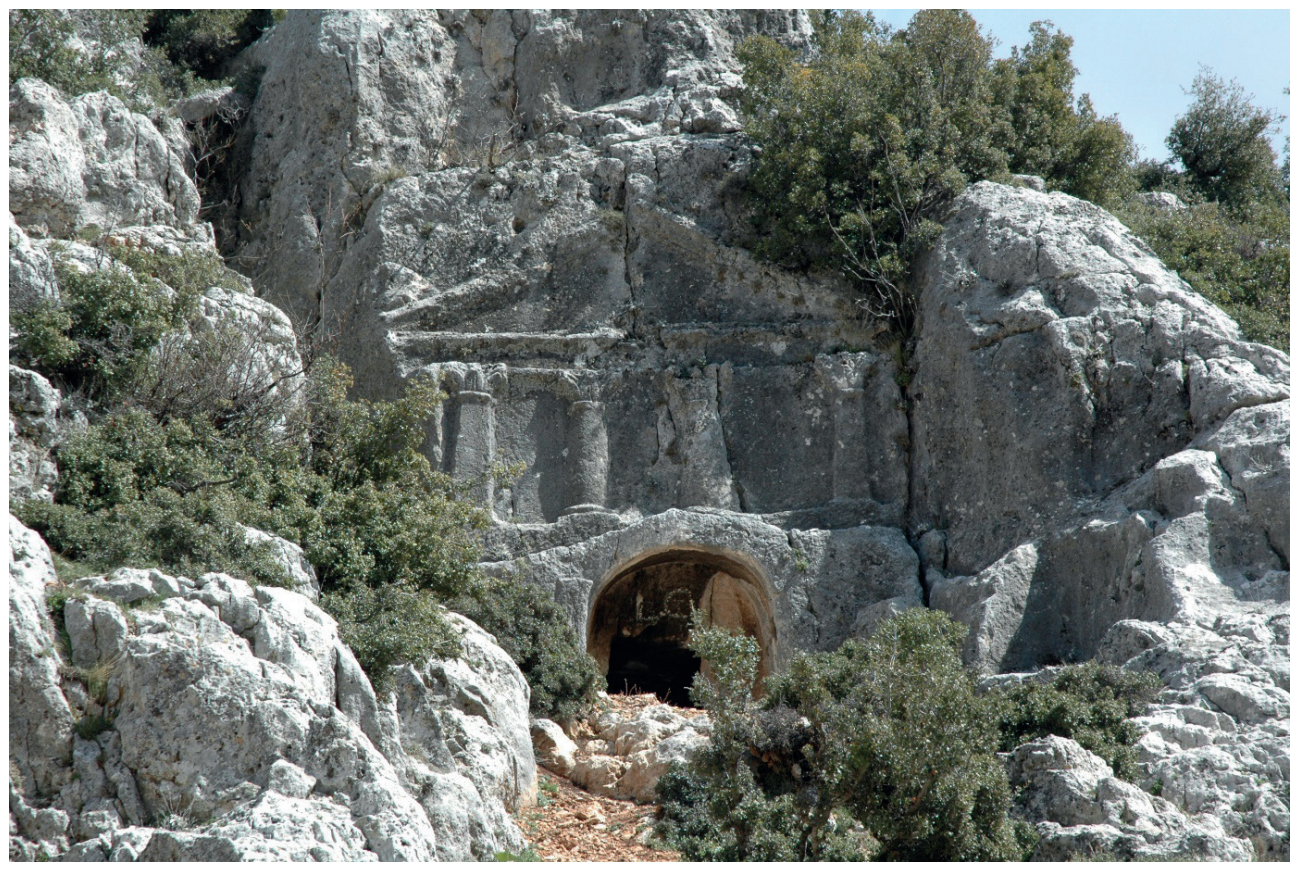

Resim 13. Olba'daki Tapınak Cepheli Korinth Kaya Mezarı.
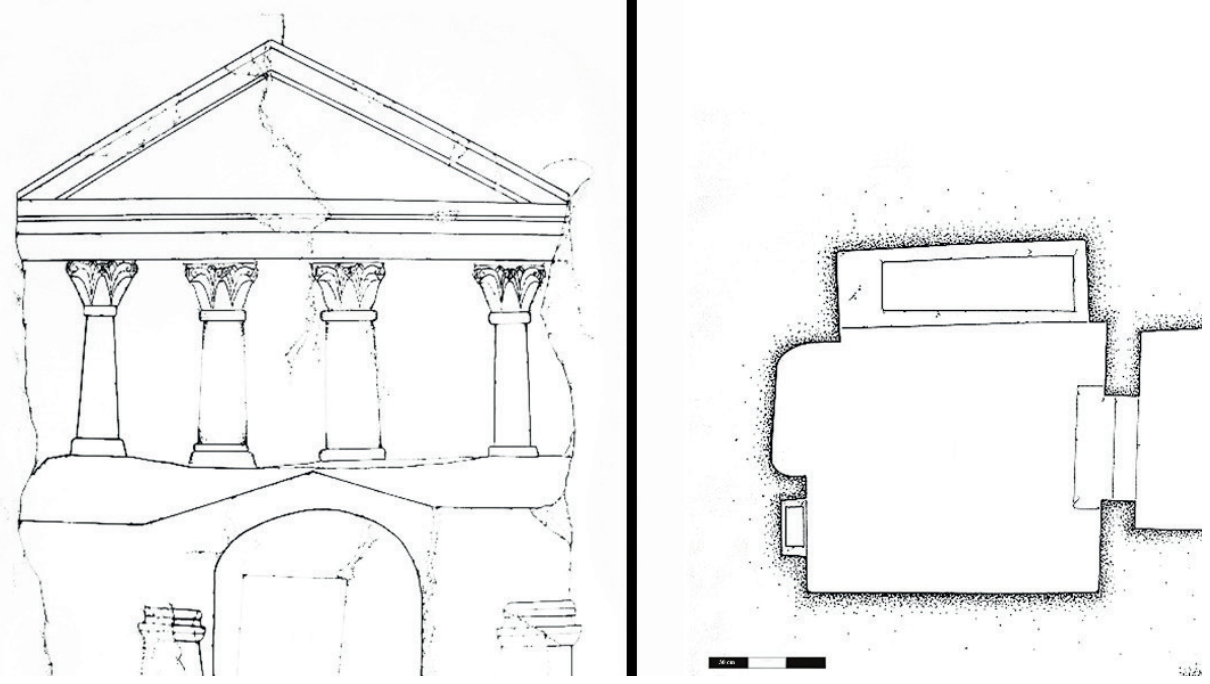

Resim 14. Olba'daki Tapınak Cepheli Korinth Kaya Mezarı'nın Planı. 


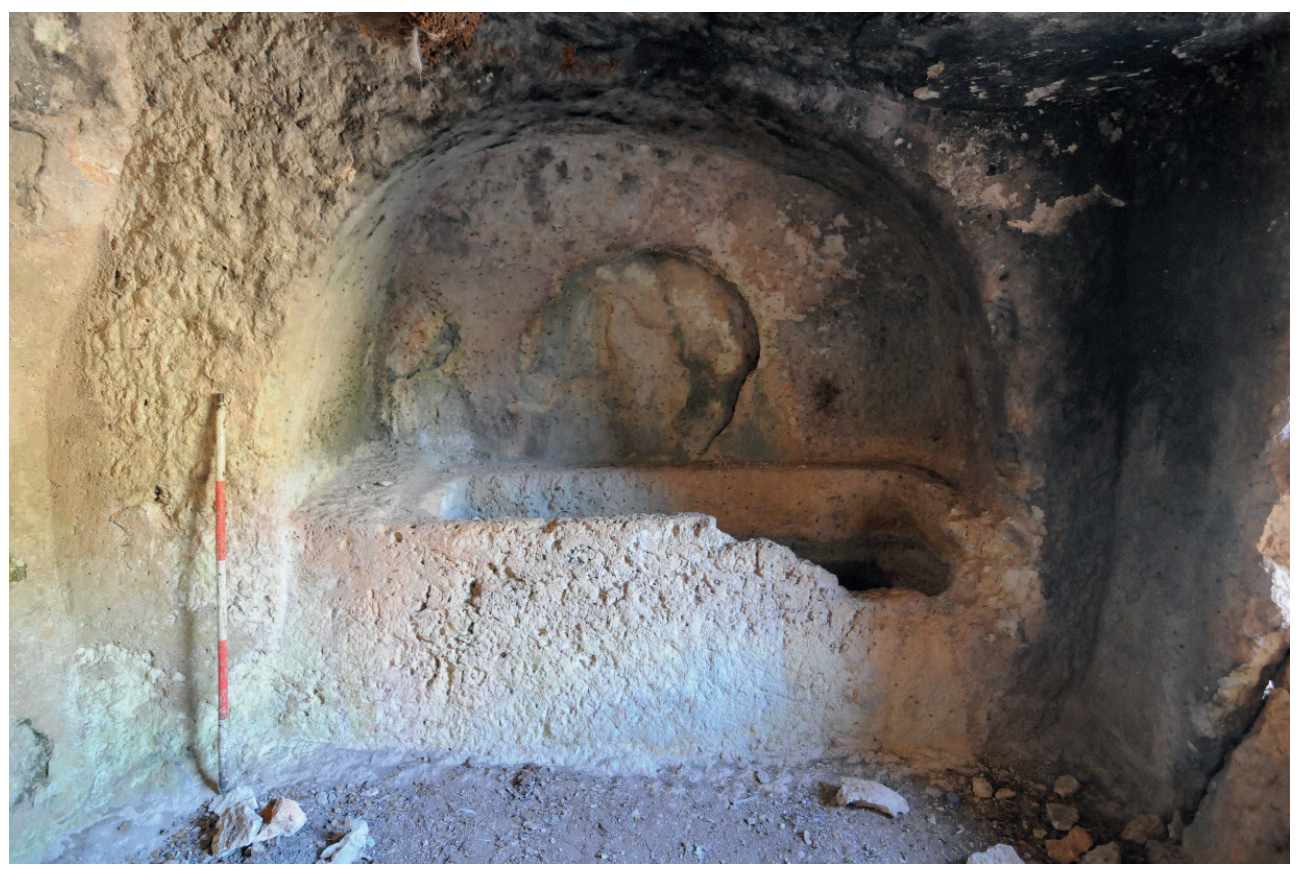

Resim 15. Olba'daki Tapınak Cepheli Korinth Kaya Mezarı'nın içindeki arcosolium. 


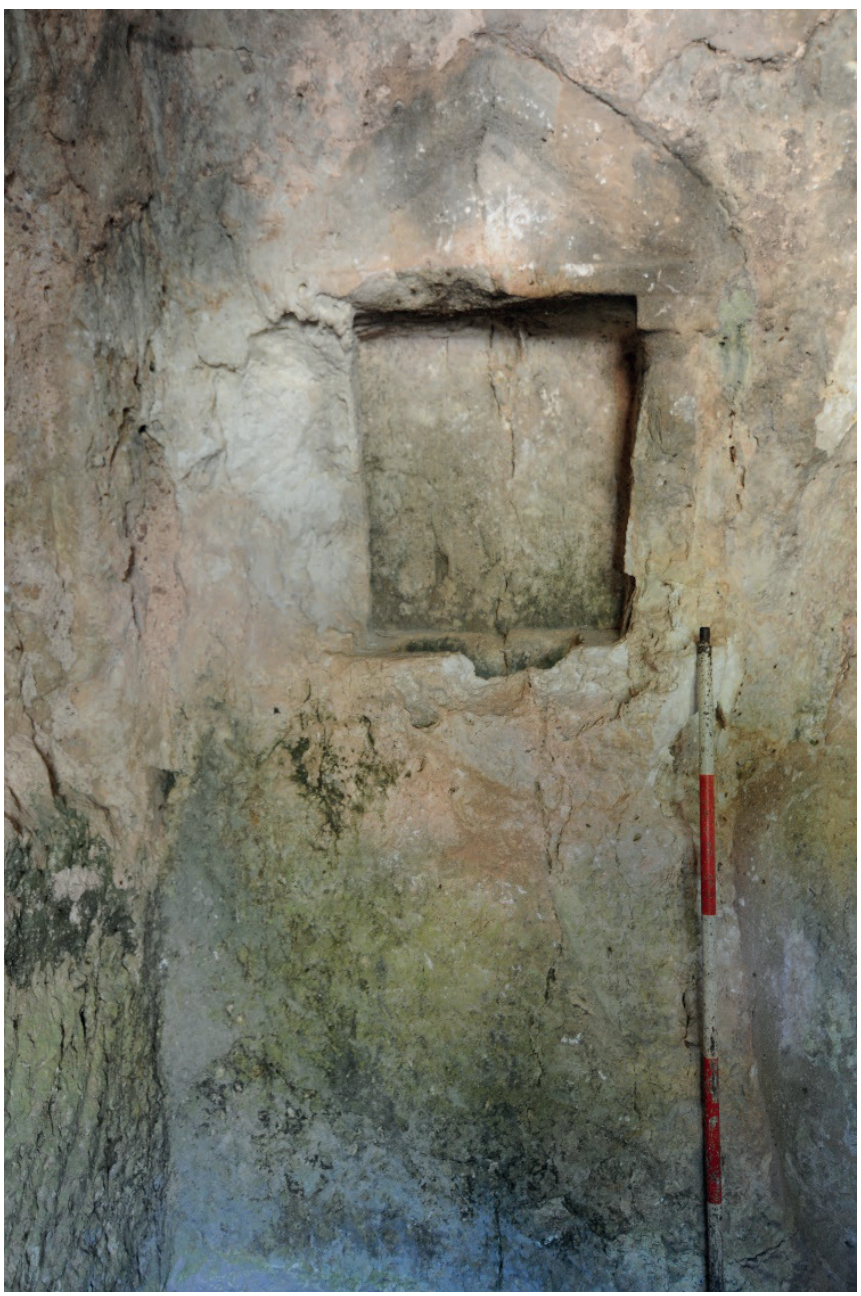

Resim 16. Olba'daki Tapınak Cepheli Korinth Kaya Mezarı'nın içindeki naiskoslu niş. 


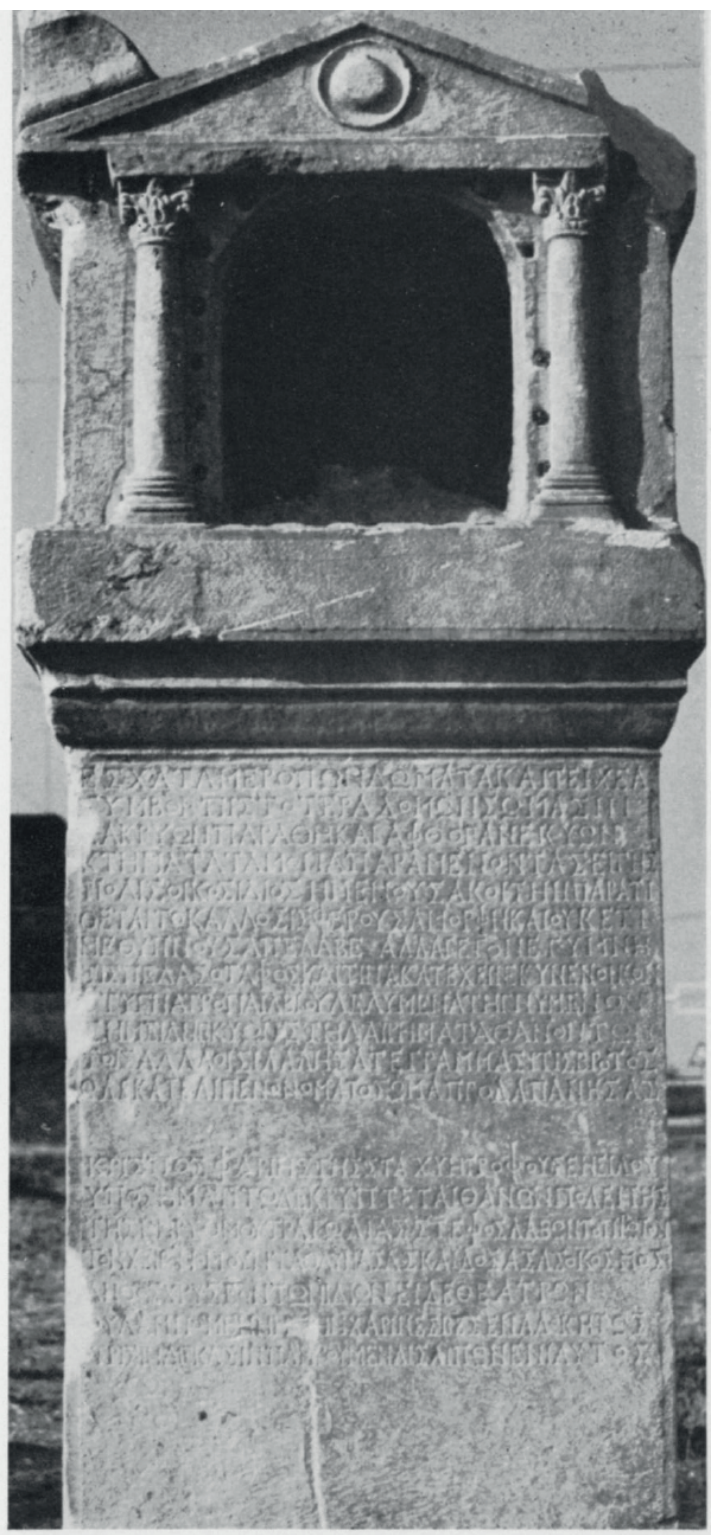

Resim 17. Heracleia Pontice'de bulunmuş bir mezar yazıtı. 